\title{
COVID-19: Coronavirus Vaccine Development Updates
}

\author{
Jing Zhao ${ }^{1+}$, Shan Zhao ${ }^{1 \dagger}$, Junxian Ou ${ }^{1}$, Jing Zhang ${ }^{2}$, Wendong Lan ${ }^{1}$, Wenyi Guan ${ }^{1}$, \\ Xiaowei Wu ${ }^{1}$, Yuqian Yan ${ }^{1}$, Wei Zhao ${ }^{1}$, Jianguo $W^{2}{ }^{2}$, James Chodosh ${ }^{3}$ \\ and Qiwei Zhang ${ }^{1,2 *}$ \\ 1 Guangdong Provincial Key Laboratory of Tropical Disease Research, School of Public Health, Southern Medical University, \\ Guangzhou, China, ${ }^{2}$ Guangdong Provincial Key Laboratory of Virology, Institute of Medical Microbiology, Jinan University, \\ Guangzhou, China, ${ }^{3}$ Department of Ophthalmology, Howe Laboratory, Massachusetts Eye and Ear, Harvard Medical \\ School, Boston, MA, United States
}

Coronavirus Disease 2019 (COVID-19) is caused by Severe Acute Respiratory Syndrome Coronavirus 2 (SARS-CoV-2), a newly emerged coronavirus, and has been pandemic since March 2020 and led to many fatalities. Vaccines represent the most efficient means to control and stop the pandemic of COVID-19. However, currently there is no effective COVID-19 vaccine approved to use worldwide except for two human adenovirus vector vaccines, three inactivated vaccines, and one peptide vaccine for early or limited use in China and Russia. Safe and effective vaccines against COVID-19 are in urgent need. Researchers around the world are developing 213 COVID-19 candidate vaccines, among which 44 are in human trials. In this review, we summarize and analyze vaccine progress against SARS-CoV, Middle-East respiratory syndrome Coronavirus (MERS-CoV), and SARS-CoV-2, including inactivated vaccines, live attenuated vaccines, subunit vaccines, virus like particles, nucleic acid vaccines, and viral vector vaccines. As SARS-CoV-2, SARS-CoV, and MERS-CoV share the common genus, Betacoronavirus, this review of the major research progress will provide a reference and new insights into the COVID-19 vaccine design and development.

Keywords: Severe Acute Respiratory Syndrome, vaccine, Coronavirus Disease 2019 (CoVID-19), Severe Acute Respiratory Syndrome Coronavirus 2, Middle-East Respiratory Syndrome

\section{INTRODUCTION}

Coronaviruses are members of the subfamily Coronavirinae composed of four genera -Alphacoronavirus, Betacoronavirus, Gammacoronavirus, and Deltacoronavirus, in the family Coronaviridae, under the order Nidovirales (1). Coronaviruses are positive sense, single-stranded RNA viruses with a spherical shape envelope, a diameter of 100-160 nm and a genome size of 27-32 $\mathrm{kb}$. The 5 ' end of the genome occupies approximately $2 / 3$ of the total length and encodes polyprotein (pplab), which is cleaved to 16 non-structural proteins involved in the transcription and replication of the genome. The 3' end encodes structural proteins, including envelope spike glycoproteins (S), envelope (E), membrane glycoprotein (M), and nucleocapsid (N) (1). S1 subunit of the spike glycoprotein mediates recognition by host receptors and S2 subunit promotes fusion of viral envelope with the cell membrane. $\mathrm{E}$ and $\mathrm{M}$ proteins are responsible for the transmembrane 
transport assembly, budding, and release of progeny viruses, and the formation of virus envelopes, all of which play an important role in virus production and maturity (2). $\mathrm{N}$ protein binds to viral RNA, which is involved in the viral gene replication cycle and immune response to viral infections of host cells $(2,3)$. Otherwise, there are species-specific accessory genes which are also essential for viral replication (1).

There are seven types of coronaviruses relevant to humans, four of which are human coronaviruses (HCoV-NL63, HCoV229E, HCoV-OC43, and HKU1), causing limited mild upper respiratory symptoms in immunocompetent populations, while the other three are highly pathogenic coronaviruses - Severe Acute Respiratory Syndrome Coronavirus (SARS-CoV), Middle East Respiratory Syndrome Coronavirus (MERS-CoV) and novel Coronavirus (SARS-CoV-2), all causing severe respiratory disease in humans.

The symptoms of SARS usually include fever, chills, and body pain, and infection can develop into pneumonia. According to WHO statistics, from November 1, 2002 to July 1 2003, 8,096 cases and 774 deaths had been confirmed with SARS-CoV infection worldwide, with a fatality rate of $9.6 \%$. MERS is a viral respiratory disease caused by MERS-CoV and was first confirmed in Saudi Arabia in 2012. MERS symptoms usually include fever, cough, and shortness of breath, and infection can also lead to pneumonia. Since 2012, MERS has spread to 27 countries and regions in the Middle East, Asia, and Europe (4), and $80 \%$ of cases are from Saudi Arabia. 2,494 cases and 858 deaths with MERS-CoV infection have been reported, with a fatality rate of about $35 \%$. The incubation period is up to 14 days, and the world population is generally susceptible. Dromedary camels are a major host of MERS-CoV and are the main source of infection of humans, with only limited human-tohuman transmission.

In December 2019, SARS-CoV-2, a novel coronavirus was identified in Wuhan, China as a new Betacoronavirus (5). This new virus causes Coronavirus Disease 2019 (COVID-19). On February 28th, WHO declared the global emergency risk level as "very high". On March 12th, the global COVID-19 outbreaks were declared as a pandemic. Many cities around the world mandated lockdowns. As of November 1st, 2020, the pandemic had caused 45,968,799 confirmed cases and 1,192,911 fatalities with the estimated case fatality rate of $2.60 \%$ (https://covid 19 . who.int/). Comparative genomic analysis showed the divergence of SARS-CoV-2 and identified 380 amino acid substitutions between SARS-CoV-2 (Wuhan/HB01 strain) and SARS$\mathrm{CoV}(6)$.

Currently, the pandemic of COVID-19 is still evolving. Effective therapeutic drugs for severe cases and effective vaccines for the healthy people are in urgent need. However, there is no specific prescription drug or effective vaccine licensed to treat or prevent COVID-19 worldwide except for four vaccines for limited use in China and two vaccines for early use in Russia.

As of October 19, 2020, among 212 SARS-CoV-2 candidate vaccines being developed all over the world, 50 have been under clinical evaluation and 162 are in preclinical development (Figure 1). Among them, there are 14 inactivated vaccines, four live attenuated vaccines, 72 protein subunit vaccines, 17 DNA vaccines, 27 RNA-based vaccines, 16 virus-like particle (VLP) vaccines, 26 non-replicating viral vector vaccines, and 18 replicating viral vector vaccines (Figure 1A). For the vaccines in clinical trials, eight are inactivated vaccines, 15 are protein subunit vaccines, six are DNA vaccines, six are RNA-based vaccines, two are VLPs vaccines, nine are non-replicating viral vector vaccines, and four are replicating viral vector vaccines (Figure 1B).

In China, there are 13 vaccine candidates that have entered clinical trials, of which six vaccine candidates are currently in phase III clinical trials. As SARS-CoV-2 is similar to the highly pathogenic SARS-CoV and MERS-CoV, experiences in the development of vaccines against other Betacoronaviruses may facilitate the COVID-19 vaccine development. In this study, we briefly review past and current $\mathrm{CoV}$ vaccine research and development against SARS (Table 1), MERS (Table 2), and SARS-CoV-2 (Table 3) (Figure 1), including inactivated vaccines, live attenuated vaccines, subunit vaccines, virus like particles, nucleic acid vaccines, and viral vector vaccines, aiming to provide a reference and new insights, to facilitate the better and faster development of COVID-19 vaccines.

\section{INACTIVATED VACCINES}

When a new pathogen emerges, for example SARS-CoV, due to the lack of understanding of the pathogenesis and therefore lengthy time to development of efficacious therapeutics, the rapid and simple development of a vaccine against the emerging infectious disease is urgently needed. Therefore, the classic approach using inactivated, cell-culture based viruses is likely to be the fastest and easiest way for $\mathrm{CoV}$ vaccine development, as we have the experience of many commercial inactivated vaccines against other viral diseases. Inactivated vaccines may maintain the normal conformation of the S protein (71). Various studies have demonstrated that vaccines based on whole, inactivated SARS-CoV potently elicit considerable levels of neutralizing antibodies in animal models (72).

\section{SARS-CoV Inactivated Vaccines}

Evaluations of a SARS-CoV whole virus vaccine doubleinactivated with formalin and UV irradiation in ferrets and nonhuman primates showed protection against infection by SARS-CoV-specific T cell and neutralizing antibody responses. The immunogenic profile elicited by double-inactivated SARS$\mathrm{CoV}$ vaccine might be not comparable to that generated by vaccine inactivated by just one approach (73). However, the challenged animals exhibited a Th2-type immunopathologic lung disease, whereas the pathologic changes seen in control groups lacked the eosinophil prominence (Tseng et al., 2012), which indicated that hypersensitivity to SARS-CoV components was induced. This may be called vaccine-associated disease enhancement (VADE) (74), which is similar to that seen with the RSV vaccine. Addition of an adjuvant in inactivated vaccines helped alleviate eosinophilic immune pathology in the lungs. 


\section{SARS-CoV-2 Vaccine Candidates}

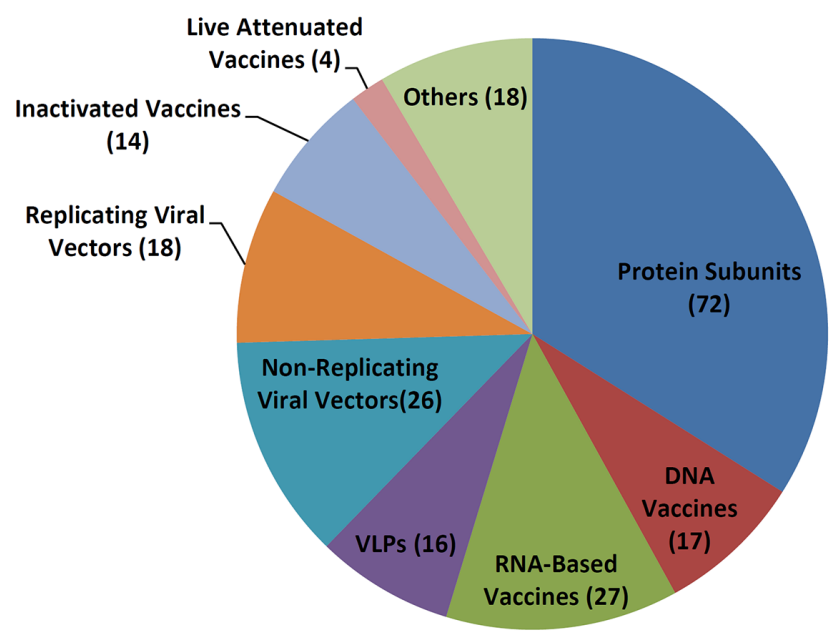

\section{SARS-CoV-2 Vaccine Candidates in Clinical Trials}

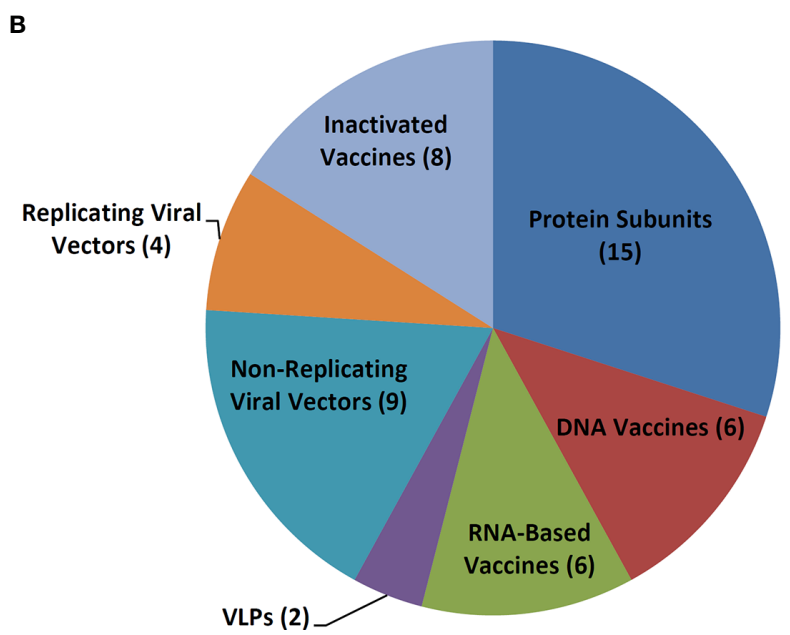

FIGURE 1 | SARS-CoV-2 vaccine candidates. (A) SARS-CoV-2 vaccine candidates in development. (B) SARS-CoV-2 vaccine candidates in clinical trials.

Inactivated SARS-CoV vaccine with $\delta$-inulin adjuvant (38) and ultraviolet inactivated SARS-CoV in toll-like receptor agonist reduced IL-4, IL-13, and eosinophil chemokines, resulting in the reduction of Th2 type eosinophilic pathology (39).

\section{MERS-CoV Inactivated Vaccines}

The gamma-ray inactivated MERS-CoV vaccine with adjuvant of alum or MF59 induced high neutralizing antibodies but caused eosinophilic lung pathological changes in vaccinated animals (75, 76). Similarly, inactivated MERS-CoV vaccine appears to carry a hypersensitive-type lung pathology risk from MERS-CoV infection that is similar to that found with inactivated SARS$\mathrm{CoV}$ vaccines from SARS-CoV infection (77). Formalin- inactivated MERS-CoV adjuvanted with alum and $\mathrm{CpG}$ induced high titers of anti-S IgG with neutralization reactivity $>60 \%$, and a stronger Th1/Th2 response in mice $(75,76)$. Both SARS-CoV and MERS-CoV vaccines inactivated by either gamma-ray or formalin induced immunopathologic lung disease in vaccinated animals, worthy of attention during the development of the inactivated SARS-CoV-2 vaccine.

\section{SARS-CoV-2 Inactivated Vaccines}

Beta-propiolactone inactivated SARS-CoV-2 vaccines have been mainly developed in China. The vaccines developed by Wuhan Institute of Biological Products/Sinopharm, Beijing Institute of Biological Products/Sinopharm, and Sinovac/Instituto Butantan/ 
TABLE 1 | SARS-CoV vaccine candidates.

\begin{tabular}{|c|c|c|c|c|c|c|}
\hline Vaccine type & Adjuvant & Animal model & $\begin{array}{l}\text { Humoral } \\
\text { immunity }\end{array}$ & $\begin{array}{l}\text { Cellular } \\
\text { immunity }\end{array}$ & $\begin{array}{l}\text { Protective } \\
\text { immunity }\end{array}$ & Reference \\
\hline RBD-FC & $\begin{array}{l}\text { MF59, Alum, } \\
\text { etc. }\end{array}$ & 129S6/SvEv mice & + & + & + & $(7-15)$ \\
\hline $\mathrm{N}$ protein & & BALB/C mice & + & + & + & $(16-19)$ \\
\hline Recombinant VLPs-S(VLPS) & Alum & BALB/c mice & + & + & + & $(20-25)$ \\
\hline DNA-S & & BALB/c mouse, human & + & + & + & $(26,27)$ \\
\hline DNA-N (pVAXN) & & BALB/c mice & + & + & & $(28)$ \\
\hline MVA-S & & $\begin{array}{l}\text { BALB/c mice, New Zealand white } \\
\text { rabbits, NHPs }\end{array}$ & + & & + & $(29-32)$ \\
\hline AdV-S & & BALB/c mice & + & + & + & $(33-35)$ \\
\hline MV-S & & CD46-IFNAR mice & + & & + & $(36,37)$ \\
\hline Inactivated vaccine & $\delta$ - inulin & mice & + & + & + & (38) \\
\hline UV-inactivated vaccine & TLR-3 & BALB/c mice & + & & + & (39) \\
\hline Inactivated vaccine SARS-CoV Z-1 & & NHPs & + & & + & $(40)$ \\
\hline Live attenuated vaccine SARS-CoV- $\Delta \mathrm{E}$ & & BALB/c mice & + & + & + & $(41,42)$ \\
\hline $\begin{array}{l}\text { Live attenuated vaccine SARS-dE-CTD\&- } \\
\text { NTD d8-12aa }\end{array}$ & & BALB/c Ola Hsd mice & + & + & + & $(43)$ \\
\hline Live attenuated vaccine nsp16 mutant & & BALB/c mice & + & & + & $(44)$ \\
\hline Live attenuated vaccine SARS-CoV-ExoN(-) & & SCID mice & + & & + & $(45,46)$ \\
\hline
\end{tabular}

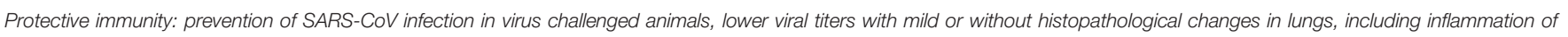
bronchial epithelium and damage of alveolar walls, eosinophilic infiltration in lung tissue, etc.

TABLE 2 | MERS-COV vaccine candidates.

\begin{tabular}{|c|c|c|c|c|c|c|}
\hline Vaccine type & Adjuvant & Animal model & Humoral immunity & Cellular immunity & $\begin{array}{l}\text { Protective } \\
\text { immunity }\end{array}$ & Reference \\
\hline RBD-FC & $\begin{array}{l}\text { MF59, Alum, } \\
\text { etc. }\end{array}$ & hDPP4-Tg BALB/c mice & + & + & + & $(47-49)$ \\
\hline RBD trimer & Alum & Mice & + & & & $(50)$ \\
\hline Nanoparticles(S) & Matrix M1 & hDPP4-Tg BALB/c mice & + & & + & (51) \\
\hline S prefusion trimer & Sigma adjuvant & BALB/cJ mice & + & & + & $(52)$ \\
\hline S1-NTD & & hDPP4-tgmice & + & + & + & $(53,54)$ \\
\hline $\begin{array}{l}\text { Recombinant VLPs (pFastBacDual-M1-St/ } \\
\text { Hak) }\end{array}$ & Alum & BALB/c mice & + & + & & $(23)$ \\
\hline BLPS (RLP3-GEM) & GEL01 & BALB/c mice & + & + & + & $(55)$ \\
\hline S DNA (pVax1TM-S) (GLS-5300) & & NHPs, Human & + & + & + & $(56,57)$ \\
\hline S DNA (pVRC8400) & $\mathrm{AlPO}_{4}$ & BALB/cJ mice, NHPs & + & & + & $(58,59)$ \\
\hline DNA+S(S1 enhancement) & & NHPs, Mice & + & & + & (58) \\
\hline DNA-S1(pcDNATM3.1 (+)-S1) & & Mice & + & + & + & $(60,61)$ \\
\hline MVA-S & & BALB/c mice, NHPs & + & + & + & $(62-65)$ \\
\hline Ad5-S/S1 & & BALB/c mice & + & & & (34) \\
\hline Ad5-S & & BALB/c mice & + & + & & (33) \\
\hline Ad41-S & & BALB/c mice & + & + & & (33) \\
\hline Ad5-S+S nanoparticle & & $\begin{array}{l}\text { AdV-hDPP4-Tg BALB/c } \\
\text { mice }\end{array}$ & & + & + & (66) \\
\hline ChAdOx1-S & & BALB/c mice, NHPs & + & + & + & $(67-69)$ \\
\hline AdC68-S & & hDPP4-KI BALB/c mice & + & + & + & $(70)$ \\
\hline
\end{tabular}

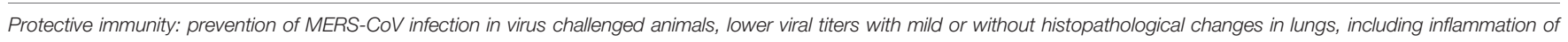
bronchial epithelium and damage of alveolar walls, eosinophilic infiltration in lung tissue, etc.

Bio Pharma have been in clinical III trials. Unlike SARS-CoV and MERS-CoV, SARS-CoV-2 inactivated vaccines showed no evidence of immunopathologic changes in the lungs of vaccinated and SARS-CoV-2 challenged animals. On June 25, 2020, the vaccine candidate of Cansino/Military Academy of Sciences was approved as special drugs for the army by the Central Military Commission's Health Bureau. On July 22, 2020, inactivated vaccine candidates of Sinopharm and Sinovac were approved for emergency use. On October 12, 2020, Sinopharm opened appointments for COVID-19 vaccination in Beijing and
Wuhan. More than 70,000 people have made appointments for vaccination.

On April 12 ${ }^{\text {th }}, 2020$, the inactivated vaccine from Wuhan Institute of Biological Products/Sinopharm was approved for clinical trials, which was the world's first inactivated SARS-CoV2 vaccine that has received clinical trial approval. In phase I/II clinical trials, the vaccine induced high titers of antibodies in different doses, with the positive rate of neutralizing antibody reaching $100 \%$ and without adverse reactions (78). Up to September 8, 2020, a phase III clinical trial was ongoing in the 
TABLE 3 | SARS-CoV-2 vaccines in clinical phase III trials and early or limited use.

\begin{tabular}{|c|c|c|c|c|c|c|c|c|}
\hline $\begin{array}{l}\text { Vaccine } \\
\text { Candidates }\end{array}$ & Developer & Country & $\begin{array}{l}\text { Vaccine } \\
\text { Platform }\end{array}$ & $\begin{array}{l}\text { Allocation \& } \\
\text { Masking }\end{array}$ & Doses & $\begin{array}{c}\text { Timing } \\
\text { of } \\
\text { doses }\end{array}$ & $\begin{array}{c}\text { Route of } \\
\text { Administration }\end{array}$ & No. \\
\hline & $\begin{array}{l}\text { Wuhan Institute Of Biological } \\
\text { Products/Sinopharm }\end{array}$ & China & Inactivated & $\begin{array}{l}\text { Randomized, } \\
\text { Double Blind, } \\
\text { Parallel Placebo } \\
\text { Controlled }\end{array}$ & 2 & $\begin{array}{l}0, \\
21 \text { days }\end{array}$ & $\mathrm{IM}$ & $\begin{array}{l}\text { ChiCTR2000031809 } \\
\text { ChiCTR2000034780 } \\
\text { ChiCTR2000039000 }\end{array}$ \\
\hline \multirow[t]{2}{*}{ BBIBP-CorV } & $\begin{array}{l}\text { Beijing Institute Of Biological } \\
\text { Products/Sinopharm }\end{array}$ & China & Inactivated & $\begin{array}{l}\text { Randomized, } \\
\text { Triple Blind } \\
\text { (Participant, Care } \\
\text { Provider, } \\
\text { Investigator), } \\
\text { Parallel Placebo } \\
\text { Controlled }\end{array}$ & 2 & $\begin{array}{l}0, \\
21 \text { days }\end{array}$ & $\mathrm{IM}$ & $\begin{array}{l}\text { ChiCTR2000032459 } \\
\text { ChiCTR2000034780 } \\
\text { NCT04560881 }\end{array}$ \\
\hline & $\begin{array}{l}\text { Sinovac/Instituto Butantan/Bio } \\
\text { Farma }\end{array}$ & $\begin{array}{l}\text { China, } \\
\text { Brazil }\end{array}$ & Inactivated & $\begin{array}{l}\text { Randomized, } \\
\text { Quadruple Blind } \\
\text { (Participant, Care } \\
\text { Provider, } \\
\text { Investigator, } \\
\text { Outcomes } \\
\text { Assessor), Parallel } \\
\text { Placebo- } \\
\text { Controlled }\end{array}$ & 2 & $\begin{array}{l}0,14 \\
\text { days }\end{array}$ & $\mathrm{IM}$ & $\begin{array}{l}\text { NCT04383574 } \\
\text { NCT04352608 } \\
\text { NCT04551547 } \\
\text { NCT04456595 } \\
\text { NCT04582344 } \\
\text { 669/UN6.KEP/EC/2020 }\end{array}$ \\
\hline Ad5-nCOV & $\begin{array}{l}\text { Cansino Biologics/Beijing Institute } \\
\text { Of Biotechnology/Canada'S } \\
\text { National Research Council/ } \\
\text { Petrovax }\end{array}$ & $\begin{array}{l}\text { China, } \\
\text { Canada }\end{array}$ & $\begin{array}{l}\text { Non- } \\
\text { Replicating } \\
\text { Viral } \\
\text { Vector }\end{array}$ & $\begin{array}{l}\text { Randomized, } \\
\text { Quadruple Blind } \\
\text { (Participant, Care } \\
\text { Provider, } \\
\text { Investigator, } \\
\text { Outcomes } \\
\text { Assessor), Parallel } \\
\text { Placebo- } \\
\text { controlled }\end{array}$ & $\begin{array}{l}1\left(5 \times 10^{10}\right. \\
\text { vp) }\end{array}$ & & $\mathrm{IM}$ & $\begin{array}{l}\text { ChiCTR2000030906 } \\
\text { ChiCTR2000031781 } \\
\text { NCT04313127 } \\
\text { NCT04341389 } \\
\text { NCT04398147 } \\
\text { NCT04526990 } \\
\text { NCT04540419 } \\
\text { NCT04566770 } \\
\text { NCT04568811 }\end{array}$ \\
\hline Sputnik V & Gamaleya Research Institute & Russia & $\begin{array}{l}\text { Non- } \\
\text { Replicating } \\
\text { Viral } \\
\text { Vector }\end{array}$ & $\begin{array}{l}\text { Randomized, } \\
\text { Double Blind } \\
\text { (Participant, } \\
\text { Investigator), } \\
\text { Parallel Placebo- } \\
\text { controlled }\end{array}$ & $\begin{array}{l}2(0.5 \mathrm{ml} / \\
\text { dose+0.5 } \\
\mathrm{ml} / \text { dose } \\
\text { prime- } \\
\text { boost })\end{array}$ & $\begin{array}{l}0, \\
21 \text { days }\end{array}$ & $\mathrm{IM}$ & $\begin{array}{l}\text { NCT04437875 } \\
\text { NCT04436471 } \\
\text { NCT04530396 } \\
\text { NCT04564716 } \\
\text { NCT04587219 }\end{array}$ \\
\hline EpiVacCorona & $\begin{array}{l}\text { Federal Budgetary Research } \\
\text { Institution (Fbri) State Research } \\
\text { Center Of Virology And } \\
\text { Biotechnology "Vector" }\end{array}$ & Russia & $\begin{array}{l}\text { Protein } \\
\text { Subunit }\end{array}$ & $\begin{array}{l}\text { Randomized, } \\
\text { Single Blind } \\
\text { (Participant), } \\
\text { Parallel Placebo- } \\
\text { controlleds }\end{array}$ & $2(0.5 \mathrm{ml})$ & $\begin{array}{l}0, \\
21 \text { days }\end{array}$ & $\mathrm{IM}$ & NCT04527575 \\
\hline $\begin{array}{l}\text { Ad26.COV2- } \\
\text { S }\end{array}$ & $\begin{array}{l}\text { Janssen Pharmaceutical } \\
\text { Companies/Beth Israel Deaconess } \\
\text { Medical Center/Emergent } \\
\text { Biosolutions/Catalent/Biological E/ } \\
\text { Grand River Aseptic Manufacturing } \\
\text { (Gram) }\end{array}$ & USA & $\begin{array}{l}\text { Non- } \\
\text { Replicating } \\
\text { Viral } \\
\text { Vector }\end{array}$ & $\begin{array}{l}\text { Randomized, } \\
\text { Quadruple Blind } \\
\text { (Participant, Care } \\
\text { Provider, } \\
\text { Investigator, } \\
\text { Outcomes } \\
\text { Assessor), Parallel } \\
\text { Placebo- } \\
\text { controlled }\end{array}$ & $\begin{array}{l}2\left(5 \times 10^{10}\right. \\
v p)\end{array}$ & $\begin{array}{l}0, \\
56 \text { days }\end{array}$ & $\mathrm{IM}$ & $\begin{array}{l}\text { NCT04436276 } \\
\text { NCT04505722 }\end{array}$ \\
\hline AZD 1222 & $\begin{array}{l}\text { University Of Oxford, Oxford } \\
\text { Biomedica, Vaccines } \\
\text { Manufacturing And Innovation } \\
\text { Centre, Pall Life Sciences, Cobra } \\
\text { Biologics, Halixbv, Advent S.R.L., } \\
\text { Merck Kgaa, The Serum Institute, } \\
\text { Vaccitech, Catalent, Csl, And } \\
\text { Astrazeneca/lqvia }\end{array}$ & UK & $\begin{array}{l}\text { Non- } \\
\text { Replicating } \\
\text { Viral } \\
\text { Vector }\end{array}$ & $\begin{array}{l}\text { Randomized, } \\
\text { Quadruple Blind } \\
\text { (Participant, Care } \\
\text { Provider, } \\
\text { Investigator, } \\
\text { Outcomes } \\
\text { Assessor), Parallel } \\
\text { Placebo- } \\
\text { controlled }\end{array}$ & $\begin{array}{l}2\left(5 \times 10^{10}\right. \\
\text { virus } \\
\text { particles } \\
(\text { vp) })\end{array}$ & $\begin{array}{l}0, \\
28 \text { days }\end{array}$ & $\mathrm{IM}$ & $\begin{array}{l}\text { CTRI/2020/08/027170 } \\
\text { EudraCT 2020-001072-15 } \\
\text { EudraCT 2020-001228-32 } \\
\text { ISRCTN89951424 } \\
\text { NCT04324606 } \\
\text { NCT04400838 } \\
\text { NCT04444674 } \\
\text { NCT04516746 } \\
\text { NCT04540393 } \\
\text { NCT04568031 } \\
\text { PACTR202005681895696 } \\
\text { PACTR202006922165132 }\end{array}$ \\
\hline
\end{tabular}


TABLE 3 | Continued

\begin{tabular}{|c|c|c|c|c|c|c|c|c|}
\hline $\begin{array}{l}\text { Vaccine } \\
\text { Candidates }\end{array}$ & Developer & Country & $\begin{array}{l}\text { Vaccine } \\
\text { Platform }\end{array}$ & $\begin{array}{l}\text { Allocation \& } \\
\text { Masking }\end{array}$ & Doses & $\begin{array}{c}\text { Timing } \\
\text { of } \\
\text { doses }\end{array}$ & $\begin{array}{c}\text { Route of } \\
\text { Administration }\end{array}$ & No. \\
\hline $\begin{array}{l}\text { NVX- } \\
\text { COV2373 }\end{array}$ & $\begin{array}{l}\text { Novavax/Emergent Biosolutions/ } \\
\text { Praha Vaccines/Biofabri/Fujifilm } \\
\text { Diosynth Biotechnologies/Fdb/ } \\
\text { Serum Institute Of India/Sk } \\
\text { Bioscience/Takeda Pharmaceutical } \\
\text { Company Limited/Agc Biologics/ } \\
\text { Polypeptide Group/Endo }\end{array}$ & India & $\begin{array}{l}\text { Protein } \\
\text { Subunit }\end{array}$ & $\begin{array}{l}\text { Randomized, } \\
\text { Quadruple Blind } \\
\text { (Participant, Care } \\
\text { Provider, } \\
\text { Investigator, } \\
\text { Outcomes } \\
\text { Assessor), Parallel } \\
\text { Placebo- } \\
\text { controlled }\end{array}$ & $\begin{array}{l}2(5 \mu \mathrm{g} \\
\text { SARS-CoV- } \\
2 \mathrm{rS}+50 \\
\mu \mathrm{g} \text { Matrix- } \\
\mathrm{M} 1 \text { adjuvant } \\
\text { (co- } \\
\text { formulated)) }\end{array}$ & $\begin{array}{l}0, \\
21 \text { days }\end{array}$ & $\mathrm{IM}$ & $\begin{array}{l}\text { NCT04368988 } \\
\text { NCT04533399 } \\
\text { EudraCT } 2020-004123-16 \\
\text { NCT04583995 }\end{array}$ \\
\hline mRNA 1273 & $\begin{array}{l}\text { Moderna/Niaid/Lonza/Catalent/ } \\
\text { Rovi/Medidata/Bioqual }\end{array}$ & USA & RNA & $\begin{array}{l}\text { Randomized, } \\
\text { Quadruple Blind } \\
\text { (Participant, Care } \\
\text { Provider, } \\
\text { Investigator, } \\
\text { Outcomes } \\
\text { Assessor), Parallel } \\
\text { Placebo- } \\
\text { controlled }\end{array}$ & $2(100 \mu \mathrm{g})$ & $\begin{array}{l}0, \\
28 \text { days }\end{array}$ & $\mathrm{IM}$ & $\begin{array}{l}\text { NCT04283461 } \\
\text { NCT04405076 } \\
\text { NCT04470427 }\end{array}$ \\
\hline BNT162 & $\begin{array}{l}\text { Biontech/Pfizer/Fosun Pharma/ } \\
\text { Rentschler Biopharma }\end{array}$ & $\begin{array}{l}\text { Germany, } \\
\text { China, } \\
\text { USA }\end{array}$ & RNA & $\begin{array}{l}\text { Randomized, } \\
\text { Triple Blind } \\
\text { (Participant, Care } \\
\text { Provider, } \\
\text { Investigator), } \\
\text { Parallel Placebo } \\
\text { Controlled }\end{array}$ & $\begin{array}{l}2(10,20, \\
30 \mu \mathrm{g} \\
\text { BNT162b1 } \\
\text { or } \\
\text { BNT162b2, } \\
\text { or } 100 \mu \mathrm{g} \\
\text { BNT162b2) }\end{array}$ & $\begin{array}{l}0, \\
28 \text { days }\end{array}$ & $\mathrm{IM}$ & $\begin{array}{l}\text { ChiCTR2000034825 } \\
\text { EudraCT 2020-001038-36 } \\
\text { NCT04368728 } \\
\text { NCT04380701 } \\
\text { NCT04523571 } \\
\text { NCT04537949 }\end{array}$ \\
\hline
\end{tabular}

UAE, Bahrain, Peru, Morocco, Argentina and other countries and regions, and this vaccine candidate is expected to be listed at the end of 2020 (https://www.echemi.com/cms/118167.html).

The inactivated vaccine from Sinovac also showed safety and effectiveness in rhesus monkeys, producing IgG and reducing virus titers and pathological changes in the lungs, without observable antibody-dependent enhancement of infection (79). On July 3, 2020, the inactivated vaccine from Sinopharm was approved for phase III clinical trial by Brazilian Health Regulatory Agency National Health Inspection Agency. On September 22, 2020, Sinovac started phase III Clinical Trials in Turkey (http://www.sinovac.com/?optionid=754\&auto_id=911).

The third SARS-CoV-2 inactivated vaccine from Beijing Institute of Biological Products/Sinopharm started phase III trials in Argentina on September 16, 2020. This inactivated SARS-CoV-2 vaccine is prepared by inoculating African green monkey kidney cells (Vero cell) with the SARS-CoV-2 HB02 strain, culturing, harvesting, inactivating, clarifying, concentrating, purifying, and adding aluminum hydroxide adjuvant. The estimated study completion date is December 1, 2021.

The inactivated SARS-CoV-2 vaccine (Covaxin) developed by Indian Bharat Biotech is the sole inactivated vaccine which has entered phase II trials outside China. The animal experiments showed robust immune responses and protective efficacy, increasing SARS-CoV-2 specific IgG and neutralizing antibodies, reducing replication of the virus in the nasal cavity, throat, and lung tissues of monkeys. No evidence of pneumonia was observed by histopathological examination in vaccinated groups nor were adverse events seen in animals immunized with a two-dose vaccination regimen (http://mtw.so/5JtMTR).

\section{LIVE ATTENUATED VACCINES}

With a long history of successful applications, such as the smallpox and polio vaccines, live attenuated vaccines are similar to natural infections with a wide range of natural viral antigen production over a long period of time and are often more immunogenic than non-replicating vaccines $(71,80)$.

$\mathrm{CoV}$ E protein induces endoplasmic reticulum stress (81) and inflammatory cytokine overexpression in host cells, causing lung tissue damage, edema, and progression to acute respiratory distress syndrome (ARDS). CoV lacking $\mathrm{E}$ protein has abnormal morphology and function due to assembly failure and maturation defects, and has been shown to inhibit the host cell's stress response $(2,82)$.

\section{SARS-CoV Vaccines}

SARS-CoV live attenuated vaccine with $\mathrm{E}$ gene deletion (SARS$\mathrm{CoV}-\Delta \mathrm{E}$ ) produced neutralizing antibodies and $\mathrm{CD} 4^{+}$with $\mathrm{CD} 8^{+}$ $\mathrm{T}$ cell responses in mice and ferrets, and reduced inflammatory cell infiltration, edema, and cell destruction $(41,42)$. When the full-length E gene was deleted or its PDZ-binding motif (PBM) was mutated, revertant viruses either evolved a novel chimeric gene including PBM, or restored the sequence of the PBM in the E protein, respectively (43). Therefore, the modified virus with partial deletion of $\mathrm{E}$ gene without affecting PBM may be a live attenuated SARS-CoV vaccine candidate. Additionally, amino acid substitutions in the transmembrane domain (TMD) of $\mathrm{E}$ protein to eliminate the ion channel activity could result in virus attenuation, which alleviated pulmonary edema in infected mice. Another SARS-CoV vaccine candidate with simultaneous 
deletion of 8-12 amino acids in both C-termini of the E and nsp1 genes enhanced IFN responses and decreased viral titers in mice $(43,83)$.

Non-structural protein 1 (nsp1) (43), nsp16 (44), and nsp14 mutants of SARS-CoV and MERS-CoV have potential as live attenuated vaccines. SARS-CoV-ExoN (-) and MERS-CoVExoN (-) are both stable mutants providing immune protection in mice with significantly reduced fidelity and moderate pathogenicity $(45,46)$. Additionally, the combination of 2'-O-methyltransferase and ExoN mutations provided effective protection in the aged mice (84). Nsp10 is a major replication regulator in SARS-CoV and its deletion generated replication-deficient viruses by interfering and preventing the activation of nsp14 ExoN (85), which indicates a potential epitope for vaccine development.

\section{MERS-CoV Vaccines}

$\mathrm{CoV}$ accessory proteins are implicated in the modulation of interferon signaling and proinflammatory cytokines (86). ORF3, $4 \mathrm{a}, 4 \mathrm{~b}$, and 5 are important for pathogenesis, and the MERS-CoV strains with combined deletion of the accessory genes $3,4 \mathrm{a}, 4 \mathrm{~b}$, and 5 (rMERS-CoV- $\triangle \mathrm{ORF} 3-5$ ) significantly weakened virulence and reduced its inhibitory effects toward IFN, becoming a possible vaccine candidate (87). Additionally, MERS-CoV nsp16 mutants induced neutralizing antibodies and reduced viral titer in mice (88). Similarly, papain-like protease (Plpro) of SARS-CoV and MERS-CoV, encoded within nonstructural protein 3 (nsp3) of the replicase polyprotein, processed the viral replicase polyprotein and deubiquitinating (DUB) or deISGylating activity, and blocked upregulation of cytokines CCL5, IFN- $\beta$ and CXCL10 in stimulated cells. Thus, mutation of Plpro of MERS-CoV inhibited the loss of IFN- $\beta$ activation (89).

\section{SARS-CoV-2 Vaccines}

There are four live attenuated COVID-19 candidate vaccines, developed by Mehmet Ali Aydinlar University \& Acibadem Labmed Health Services A.S., Meissa Vaccines, Indian Immunologicals LTD \& Griffith University, and Codagenix/ Serum Institute of India, respectively. However, none of these vaccines have entered clinical trials. Among these vaccines, the vaccine candidate developed by Codagenix/Serum Institute of India is the earliest vaccine made in India and could induce strong immune responses. The vaccine was in the preclinical stage in April and is expect to enter clinical trials in September 2020.

The Bacillus Calmette-Guerin (BCG) vaccine was designed to protect against tuberculosis (TB). It boosts immunity by 'training' the immune system to respond to other subsequent infections with greater intensity. In order to find out whether it could reduce the risk of COVID-19 infection among healthcare staff and care home workers who are particularly vulnerable to coronavirus infection, this vaccine candidate is entering a phase III "BRACE" trial with up to 10,078 healthcare workers in hospitals in Australia as participants. In Netherlands, it is in phase IV trial and is enrolling 5,200 elders as participants (https://clinicaltrials.gov/ct2/results? cond=COVID\&term=
$\mathrm{BCG}+\& \mathrm{cntry}=\&$ state $=\& \operatorname{city}=\&$ dist $=;$ https://www.mcri.edu.au/ news/could-bcg-vaccine-protect-against-covid-19-ukrecruitment-begins-0).

\section{SUBUNIT VACCINES}

Subunit vaccines are comprised of purified immunogenic proteins or peptides (90) derived from viruses. In contrast with traditional vaccines, subunit vaccines have less side effects and higher safety at the injection site. However, whether the immunological memory will be formed in the correct manner is not guaranteed. Therefore, adjuvants as well as vaccine delivery systems are needed to enhance immune responses (91).

\section{Spike/RBD-Targeted Subunit Vaccines SARS-CoV S/RBD Vaccines}

Most of $\mathrm{CoV}$ subunit vaccines focus on the $\mathrm{S}$ protein. $\mathrm{S}$ protein is the outermost localized protein responsible for receptor binding, especially its highly immunogenic receptor binding domain (RBD) (47), a critical region for receptor interaction (48).

In recent years, Pichia pastoris yeast have served as an expression system for producing a large number of modified proteins in the culture medium without animal-derived growth factors, thus widely applying to the pharmaceutical and vaccine industries. RBD $219 \mathrm{~N}-1$ protein, in which an $\mathrm{N}$-linked glycosylated asparagine at the N-1 position of RBD219 has been deleted, expressed by P. pastoris, induced strong RBD-specific neutralizing antibody responses during pseudovirus and live SARS-CoV infections. Manufacture of recombinant RBD219-N1 protein was achieved with higher purity after optimizing the process $(7,8)$.

Recombinant fusion protein (RBD-Fc) containing 193-amino acid RBD (residues 318-510) and a human IgG1 Fc fragment with higher purification and stability as a vaccine candidate, enhanced antigen-presenting cell recognition by inducing strong neutralizing antibody and cellular immune responses and long-term protective effects in mice against SARS-CoV challenge (9-11).

\section{MERS-CoV S/RBD Vaccines}

The MERS-CoV spike protein forms a trimer, and its receptorbinding domain (RBD) serves as a vaccine target. RBD-Fd, a trimeric protein generated by fusing $\mathrm{RBD}$ with foldon trimerization motif (50). The outcomes indicated the potential of developing MERS subunit vaccines based on the trimeric RBD of MERS-CoV $S$ protein. In a further study it was found that compared with Freund's adjuvant, aluminum, monophosphorylate lipid A, and Montanite ISA 51, the combination of S377-588 protein fused with Fc of human IgG (S377-588-Fc) and MF59 adjuvant induced the highest titers of IgG, IgG1, and IgG2a subtypes and neutralizing antibodies after intranasal vaccination (49). Proline-substituted variants of MERS-CoV S2 domain retained S2 in the prefusion conformation, therefore producing a fully stable $S$ trimer vaccine for broader and stronger neutralizing activity. Adjuvanted MERS-CoV S protein nanoparticles injected intramuscularly induced even higher levels of neutralizing antibodies (51). 
'Neutralizing immunogenicity index' (NII) is a novel concept to evaluate the neutralizing immunogenicity of different epitopes on viral subunit vaccines. NII was used as a tool to identify epitopes with different neutralizing immunogenicity on a MERSCoV-RBD-based vaccine. By application of this tool, subunit vaccines against MERS-CoV were rationally designed and found to significantly enhance the efficacy of the MERS-CoV RBD vaccine in protecting human-DPP4-transgenic mice from lethal MERS-CoV challenge (92). This methodology may guide the rational design of highly effective subunit vaccines to combat SARS-CoV-2.

\section{SARS-CoV-2 Subunit Vaccines}

B-cell and T-cell epitopes are highly conserved between SARSCoV-2 and SARS-CoV. The vaccine against a conserved epitope may elicit cross-immune responses to mutant viruses (93). Analysis of T-cell and B-cell epitopes of SARS-CoV revealed that viral mutations mainly targeted epitopes that were highly expressed by MHC-I, while no mutations were found near RBD. In combination with other epitopes, recombinant SARS-CoV-2 S protein is a feasible vaccine candidate.

There are more than 60 subunit vaccines against SARS-CoV2 under development, including RBD-trimer of S protein, S1, recombinant S proteins, N, M proteins, and others. One of them is in phase III clinical trial, four are in phase II trials, and seven are in phase I trials.

Novavax's SARS-CoV-2 subunit vaccine candidate NVXCoV2373 was based on Matrix-M -adjuvanted recombinant protein vaccine with nanoparticle technology using the Sf9 system. It has entered phase I/II clinical trials in May 2020, and has shown outstanding results so far without severe adverse events. It induced high titers of neutralizing antibodies and $S$ protein specific IgG, as well as Th1 biased immune response while two doses of $5 \mu \mathrm{g}$ of adjuvanted NVX-CoV2373 resulted in effective protection in non-human primate experiments, indicating the potential to protect humans (94) (https://ir.novavax.com/newsreleases/news-release-details/novavax-initiates-phase-3-efficacytrial-covid-19-vaccine-united). On September 24, 2020, Novavax initiated a phase III study of its vaccine candidate, expecting to enroll and immunize up to 10,000 individuals between 18 and 84 (inclusive) years of age in the UK. This is the fastest developed subunit vaccine against SARS-CoV-2.

In China, the SARS-CoV-2 RBD-dimer subunit vaccine by Anhui Zhifei Longcom/Institute of Microbiology, Chinese Academy of Sciences has entered a phase II clinical trial in July (https://clinicaltrials.gov/ct2/show/NCT04466085?term= NCT04466085\&draw=2\&rank=1). In Russia, on August 26, the Vector Institute registered a phase I/II trial for a subunit vaccine called EpiVacCorona. On October 14, Vladimir Putin announced that EpiVacCorona was granted regulatory approval to use in Russia. This is the second vaccine for limited use in Russia after the Gamelaya Institute's Sputnik V vaccine. The third subunit vaccine which has entered phase I/II trials was developed by Sanofi/GSK. They launched a phase I/II clinical trial in September and plan to start a phase III trial in December. The fourth RBD subunit vaccine Soberana 1, which has entered phase I/II trials, was developed by Finlay Vaccine
Institute in Havana, Cuba. It contains two extra ingredients: proteins from a bacteria and aluminum hydroxide as adjuvants (https://rpcec.sld.cu/ensayos/RPCEC00000332-Sp).

There are seven other SARS-CoV-2 subunit vaccines in phase I trials, developed by Medigen Vaccine Biologics Corp, Vaxine Pty Ltd, Clover Biopharmaceuticals and Gsk, Covaxx, University of Queensland, West China Hospital of China, and Adimmune Corporation. The safety and efficacy of these subunit vaccines should be verified in clinical trials.

\section{Nucleocapsid Proteins $\mathbf{N}$ as Immunological Target}

During the SARS epidemic, it was found that the titer of neutralizing antibodies against $S$ protein was significantly higher in deceased patients, while the anti-N protein antibody titer was lower during the early stages of infection $(16,17)$. In contrast, the anti-N antibody rose more rapidly in recovered patients $(18,95)$. The efficacy of anti$\mathrm{N}$ antibody deserves further exploration.

In MERS-CoV, the B-cell, helper T-cell and cytotoxic $\mathrm{T}$ lymphocyte (CTL) epitopes were screened and mapped to the $\mathrm{N}$ protein, and are potential epitopes for vaccine candidates to elicit protective neutralizing antibodies and cellular immune responses against MERS-CoV (96). Along with the importance of T-cell-based cellular immunity, and escape of neutralizing antibodies against $S$ protein of MERS-CoV due to its high mutation rate, $\mathrm{N}$ protein, rather than $\mathrm{S}$ protein, could be a suitable immunogen candidate with the potential to elicit both humoral and cell mediated immune responses (96). Currently the primary focus has been the spike protein. Whether the SARSCoV-2 N protein is another potential immunological target for vaccines needs to be further verified.

\section{VIRUS-LIKE PARTICLES (VLPS) AND BACTERIA-LIKE PARTICLES (BLPS)}

Virus-like particles (VLPs) are similar to intact virions in size and morphology. Without a viral genome, VLPs are unable to replicate or reverse mutate, suggesting better safety, especially for viruses that cause high morbidity and mortality. They may induce strong and broad humoral and cellular immune responses $(20,21,97)$.

\section{SARS-CoV Vaccines}

The S, M, and $\mathrm{N}$ proteins of the SARS-CoV are necessary and sufficient for pseudovirus assembly (25). Coexpression of SARS$\mathrm{CoV} S$ protein and $\mathrm{E}, \mathrm{M}$ and $\mathrm{N}$ proteins in mouse hepatitis virus (MHV) resulted in efficient production of MHV VLPs and protected the vaccinated mice from infection. Compared with the control groups, MHV VLPs adjuvated with alum induced high titers of neutralizing antibodies and reduced SARS-CoV titers as well as inflammation in the lung (22). Moreover, the influenza M1 protein is also a common core protein, suggesting the possibility of application to SARS-CoV VLP production. Researchers produced chimeric SARS VLPs (cVLPs) containing the spike protein of SARS and the matrix protein of influenza virus. VLPs with alum as an adjuvant induced significantly 
higher titers of neutralizing antibodies and protected mice against virus challenge, and led to lower virus titers after intramuscular immunization (98).

\section{MERS-CoV Vaccines}

The avian influenza M1 was also used as a core protein to generate cVLPs containing modified S protein of MERS-CoV. This recombinant immunogenic cVLP significantly increased neutralizing antibodies and IgG against $S$ protein of MERS-CoV in mice (23). Besides VLPs, a BLP vaccine candidate displaying the MERS-CoV RBD with GEL01 adjuvant also induced humoral, cellular, and local mucosal immune responses in the mouse model, especially in the intestinal tract, indicating its promise as a vaccine candidate (55). This BLP contains three lysin motif (LysM) motifs in an anchor protein combined with MERS-CoV RBD to form RBD-linker-PA3 ( $\left.\mathrm{RLP}_{3}\right)$. Grampositive enhancer matrix (GEM) particles were used as substrates to externally bind to the MERS-CoV RBD through a protein anchor. BLPs are a novel platform and have broad prospects in vaccine development.

\section{SARS-CoV-2 Vaccines}

Fifteen VLP COVID-19 vaccines are in development. Among them, the vaccine developed by Medicago Inc. is the earliest and started in phase I trials in July 2020. The phase II/III trial is expected to start in November. This is a plant-derived VLP vaccine with GSK or Dynavax adjuvants. It uses the same platform as vaccine candidates for flu, rotavirus, norovirus, West Nile virus, and cancer.

Another VLP vaccine developed by SpyBiotech/Serum Institute of India entered phase I/II trials in September in Australia (https://www.spybiotech.com/news/-). This VLP displayed the RBD of SARS-CoV-2 S protein on the surface of Hepatitis B surface antigen (HBsAg) VLPs, which is safe and immunogenic and has been made in mass production.

The other VLP vaccines are still in preclinical phase. If the immunogenicity is proven, VLPs and BLPs are promising vaccine candidates for SARS-CoV-2 and other life-threatening viruses.

\section{NUCLEIC ACID VACCINES}

Nucleic acid vaccines are genetic vaccines consisting only of DNA or RNA, which are taken up and translated into protein by host cells and elicit immune responses. Because they contain no viral coat, naked nucleic acids are not generally subject to preexisting immunity that can hamper the clinical efficacy of recombinant virus vaccines. In terms of higher safety and lower cost of production, nucleic acid vaccines have some major advantages over other types. Post-translational modifications under natural conditions are reproduced by the plasmidencoded protein, retaining immunogenicity (99) and humoral and cellular immune-stimulating capabilities, simultaneously (24). Although there have been concerns about the safety of DNA vaccines in these early stages of development (100), it appears that viral genes integration into host genes through plasmid vectors is extremely rare (101).

\section{DNA Vaccines}

\section{SARS-CoV Vaccines}

S Gene

SARS-CoV S DNA vaccines produced high levels of IgG against $\mathrm{S}$ protein (26) and $\mathrm{CD}^{+}$and $\mathrm{CD}^{+} \mathrm{T}$ cell responses (27). Furthermore, serum $S$ protein-specific IgG1 and IgA in the respiratory tracts of mice were significantly elevated through PEI/pci-S complexes formed by polyethyleneimine (PEI) and SARS DNA vaccine, along with increases in IFN- $\gamma$, TNF- $\alpha$, and IL-2 expression.

\section{$N$ Gene}

Raghuwanshi et al. found that plasmid DNA loaded biotinylated chitosan nanoparticles for nasal immunization against $\mathrm{N}$ protein induced $\mathrm{N}$ protein-specific IgG, mucosal IgA, and IFN- $\gamma$ expression in mice. When combined with CD40 monoclonal antibody, this vaccine induced higher antibody titers through intramuscular administration than by intranasal vaccination (28). Following intranasal delivery of naked pDNA, no mucosal and systemic immune responses were detected.

\section{MERS-CoV Vaccines}

There are several DNA vaccines of MERS-CoV under development: pVax1 ${ }^{\mathrm{TM}}$ (GLS-5300), pVRC8400, and pcDNA3.1-S1 encoding MERS-CoV S1 subunit (56-60). These induced neutralizing antibodies and cellular immune responses in rhesus monkeys, camels, and mice. The IgG and specific cellular response levels of S1 subunit were higher than for $S$ protein. A more balanced Th1/Th2 response avoided the potential safety issues of the $S$ gene vaccines, i.e. the immunopathology and disease enhancement reported in SARS-CoV vaccine candidates $(102,103)$. The $\mathrm{pVax}^{\mathrm{TM}}$ vaccine (GLS-5300) has completed phase I clinical trials. Most participants had three doses of vaccination, and anti-S1 subunit antibodies could still be detected after one year. The humoral and cellular immune responses of the subjects were similar to those recovering from natural infection of MERS-CoV. The vaccine was well tolerated, and no serious vaccine-related adverse events have been reported $(57,61)$.

Additionally, the MERS-CoV S protein vaccine supplemented with enhanced S1 subunit expression induced neutralizing antibodies and reduced disease severity in non-human primates (NHPs). Compared with pure protein and peptide vaccines, the combination of DNA and protein resulted in a more functional antibody library and stronger Th1 cell immune response (58).

\section{SARS-CoV-2 Vaccines}

Four DNA vaccine candidates have been studied in phase II clinical trials, including those developed by Inovio Pharmaceuticals (INO-4800), Zydus Cadila Healthcare Limited (ZYCOV-D), Osaka University (DNA plasmid+adjuvant), and Genexine consortium (GX-19), respectively. All these vaccine candidates are based on the spike protein, and have shown immunogenicity and protection in animals. Other DNA vaccines are still in preclinical stages.

INO-4800, a potential COVID-19 DNA vaccine candidate targeting SARS-CoV-2 S protein, induced effective humoral 
responses in mice and guinea pigs, and protected animals from lower respiratory disease (104). In early April, Inovio Pharmaceuticals started phase I clinical trials. 94\% of participants developed the expected immune responses, including neutralizing antibodies and $\mathrm{T}$ cell immune responses without serious adverse reactions (http://ir.inovio.com/newsreleases/news-releases-details/2020/INOVIO-AnnouncesPositive-Interim-Phase-1-Data-For-INO-4800-Vaccine-forCOVID-19/default.aspx). Phase IIa trials began in July 2020. However, Inovio announced a partial clinical hold for its phase II/III trial of on September 28, 2020. There were additional questions about INO-4800 reported to the US Food and Drug Administration (FDA), including its CELLECTRA ${ }^{\circledR} 2000$ delivery device. The phase II/III clinical trial will continue only when these questions have been satisfactorily answered (http://ir.inovio.com/ news-releases/news-releases-details/2020/INOVIO-Reports-FDAPartial-Clinical-Hold-for-Planned-Phase-2-3-Trial-of-COVID19-Vaccine-Candidate-INO-4800/default.aspx).

In Korea, a DNA vaccine for COVID-19 named GX-19 developed by Genexine Inc. began phase I/IIa clinical trials in June 2020, expected to be completed by 2021 (https://www. bioworld.com/articles/435995-south-koreas-genexine-beginsphase-iiia-trials-for-covid-19-vaccine).

In Japan, a SARS-CoV-2 DNA vaccine developed by Osaka University/Anges/TAKARA BIO/Cytiva/Brickell BioTech is currently in phase I/II clinical studies (https://www.anges.co.jp/ pdf_news/public/IGiJ94QWoV9U7EIYJybHY6SNv3BxVXRN. pdf). In India, a SARS-CoV-2 DNA vaccine given by intradermal route was developed by Cadila Healthcare Limited. It entered phase I trial in July 2020 and phase II in August 2020 (http://ctri. nic.in/Clinicaltrials/pmaindet 2 .php?trialid $=45306 \&$ EncHid $=$ \&userName=vaccine).

\section{Conventional mRNA Vaccine}

mRNA is a minimal and transient information carrier. It does not interact with the host genome, and is safe and can be manufactured rapidly. Any protein can be encoded and expressed by mRNA, which offers maximum flexibility with respect to the development of vaccines for infectious diseases and cancer as well as protein replacement therapies (105). The conventional mRNA vaccines translate the immunogens of interest from the input vaccine transcript.

While direct delivery into the cytosol would certainly enhance antigen expression, a lack of interaction with endosomal RNA receptors may severely weaken immunostimulation by the vaccine (105). Thus, suitable liposomes and complexing agents have been selected to enhance uptake by cells, improve delivery to the translation machinery in the cytoplasm, and prevent degradation of mRNA (105).

With the advantages of high efficiency, safety, low production cost, and the potential for rapid large-scale production, mRNA vaccines have become an attractive alternative to traditional vaccines, with a promising future. In animal models of infectious disease caused by influenza virus, Zika virus, rabies virus, the subcutaneous or intramuscular injection of liposomeencapsulated mRNA $(106,107)$ or a naked mRNA vaccine through subcutaneous or intranasal injection (108-111) induced effective immunity (106).

Several different mRNA vaccines exhibited high safety and tolerability in different stages of clinical trials. Nonetheless, the risk of an autoimmune response and/or promoting pathological thrombosis (112-115), or severe injection site or systemic reactions $(107,116)$ still exists in the application of extracellular RNA. Therefore, the safety of mRNA vaccines needs further evaluation. Moreover, the production of mRNA vaccines depends on a transcription system in vitro. When the production scale and speed cannot keep up with the speed of change in the epidemic, large-scale production applications remain challenging.

mRNA vaccines against SARS-CoV-2 developed by Moderna, BioNtech/Pfizer, Curevac, Arcturus, Academy of Military Sciences of China, Chulalongkorn University, and AstraZeneca/Shenzhen Kangtai have entered clinical trials. Among them, Moderna entered phase III trial in July, BioNtech/Pfizer started phase IIb/III trials in July, Curevac started IIa trials in September, Imperial College London started phase I/II trials in June, Arcturus started phase I/ II trials in August, and Academy of Military Sciences of China started phase I trials in June. The others are still in development.

The mRNA-1273 vaccine candidate developed by Moderna is the most promising mRNA vaccine to date. This vaccine encodes the prefusion-stabilized spike protein of SARS-CoV-2, and induced $S$ protein specific IgG antibodies in rhesus monkeys after the second vaccination. The vaccination induced type 1 helper T-cell (Th1)biased CD4 T-cell responses and low or undetectable Th2 or CD8 $\mathrm{T}$-cell responses in nonhuman primates. Compared to the inflammation of airways and adjacent alveolar interstitial found in the control group, animals in the mRNA-1273 group developed only mild inflammation and no viral RNA or antigen was detected in their lungs (117). In early July 2020, Moderna completed enrollment for both cohorts of its phase II study. The vaccine induced anti-SARS-CoV-2 immune responses in all participants, and no trial-limiting safety concerns were identified. Antibody titers were higher after the second vaccination (118). Later in July, Moderna launched a phase III clinical trial (https://investors. modernatx.com/news-releases/news-release-details/modernaannounces-phase-3-cove-study-mrna-vaccine-against-covid).

Another hopeful mRNA vaccine BNT162 was developed by BioTech/Fosun Pharma/Pfizer. Two mRNA candidate vaccines were evaluated in the phase I portion of the trial in the United States: one was BNT162b1, encoding a secreted trimerized SARS-CoV-2 receptor-binding domain, and the other was BNT162b2, encoding a membrane-anchored SARS-CoV-2 fulllength spike, which was stabilized in the prefusion conformation. BNT162b2 was associated with a lower incidence and severity of systemic reactions than BNT162b1, particularly in older adults (119). In both younger and older adults, the two vaccine candidates elicited similar dose-dependent SARS-CoV-2neutralizing geometric mean titers (119). A phase IIb/III trial was launched in July 2020. On November 9, they announced that the vaccine candidate BNT162b2 was found to be more than $90 \%$ effective in preventing COVID-19 in participants without evidence of prior SARS-CoV-2 infection in the first interim efficacy analysis from the phase III clinical study (https://www. 
pfizer.com/news/press-release/press-release-detail/pfizer-andbiontech-announce-vaccine-candidate-against). The trial is continuing to enroll and is expected to continue through the final analysis when a total of 164 confirmed COVID-19 cases have accrued.

$\mathrm{CVnCoV}$ is a mRNA vaccine developed by Curevac. They launched a phase IIa clinical trial on September 29, 2020. Curevac reported preclinical trial data through October 23, 2020. After the second vaccination, titers of neutralizing antibodies and IgG were significantly higher and more lasting. The IgG2a/IgG1 ratios showed a balanced Th1/Th2 profile, and the vaccine appeared to avoid vaccine-induced disease enhancement (https://www.curevac.com/en/2020/10/23/ curevac-reports-positive-preclinical-data-for-its-covid-19vaccine-candidate-cvncov/).

The other mRNA vaccine candidate that entered human phase I/II clinical trials in June was developed by Imperial College London (https://www.imperial.ac.uk/news/198314/ imperial-begin-first-human-trials-covid-19). In China, the first COVID-19 mRNA vaccine approved for clinical trials was ARCoV, developed by the People's Liberation Army (PLA) Academy of Military Sciences, Suzhou Abogen Biosciences, and Walvax Biotechnology Co., Ltd. Their study showed that the COVID-19 mRNA vaccine not only induced high levels of neutralizing antibodies in mice and crab-eating macaques but also induced protective $\mathrm{T}$ cell immune responses (120). ARCoV is currently being evaluated in phase 1 clinical trials. Other mRNA vaccine candidates showed immunogenicity by eliciting potent neutralizing antibodies in mice and/or NHPs $(121,122)$.

\section{Self-Replicating RNA Vaccine (saRNA)}

Self-amplifying RNA (saRNA) is derived from an alphavirus genome, which encodes the alphaviral replicase and a gene of interest. It amplifies sub-genomic RNA carrying the antigen of interest, resulting in the amplification of transcripts bearing the antigen by several orders of magnitude over the initial dose (123). saRNA is a highly efficient platform for SARS-CoV-2 vaccine development.

Currently, among several saRNA vaccine candidates against SRAS-CoV-2, LUNAR-COV19 developed by Arcturus Therapeutics and Duke-NUS Medical School is the sole one in clinical trials. This vaccine encodes SARS-CoV-2 full length $S$ protein and requires a much smaller dose than the conventional mRNA vaccine, $~ 50$ to 100 times less, which would greatly lower the cost per dose. Mice vaccinated with a single dose of LUNARCOV19 induced stronger $\mathrm{T}$ cell responses and significantly higher levels of S protein specific IgG lasting for 50 days after vaccination, as well as robust neutralizing antibodies. Similarly, Th1 biased immune responses were shown in this study, and LUNAR-COV19 also protected mice from SARS-CoV-2 lethal challenge and even measurable infection (124).

\section{VIRAL VECTOR VACCINES}

Viral vector vaccines can effectively introduce genes encoding viral antigens into host cells. The infected cells produce and release immunogenic antigens within a certain period after vaccination (80). Subunit vaccines and protein-induced immune responses are usually short-lived, and consequently multiple injections are usually required to induce and maintain a systemic immune response. In contrast, nonattenuated viral vectors can invade cells naturally, thus activate the immune system and induce stronger humoral and cellular immune responses. Several viral vectors for $\mathrm{CoV}$ vaccines have been developed, such as adenovirus (AdV), modified vaccinia virus Ankara (MVA), measles virus (MV), Venezuelan equine encephalitis virus (VEE), vesicular stomatitis virus (VSV), Newcastle disease virus (NDV), rabies virus (RV), RSV, and others $(125,126)$. These virus-based vectors provide innovative directions and routes for $\mathrm{CoV}$ and other virus vaccine research and development. Through November 3, 2020, 18 replicating viral vector vaccines and 26 non-replicating viral vector vaccines were under development for COVID-19. The former are designed mainly on measles virus, VSV, influenza virus, avian paramyxovirus, and NDV. The latter are based mainly on human adenovirus types 5 or 26 , chimpanzee adenovirus, Parainfluenza Virus 5(PIV5), influenza virus, $\mathrm{AAV}$, and MVA.

\section{Adenovirus Vectored Vaccines SARS-CoV Vaccines}

Human adenovirus type 5 (HAdV-5) vectored vaccines have been extensively developed $(33,34)$. HAdVs can effectively induce mucosal immune responses, and have been widely studied for their wide host range, strong infectivity, high protein expression, and high safety when imbued with a replication defect. Compared with intramuscular injection, both intranasal and sublingual administration of recombinant adenoviruses encoding SARS-CoV spike protein elicited stronger $\mathrm{CD}^{+}$cell response and higher levels of neutralizing antibodies and IgA without VADE (35).

\section{MERS-CoV Vaccines}

A single injection of the MERS-CoV S protein-coding HAdV5 or $\mathrm{HAdV}-41$ vectored vaccines elicited mucosal and systemic immunity in mice $(33,34)$. When boosted with $\mathrm{S}$ nanoparticles, the vaccine induced S-specific IgG neutralizing antibodies, as well as Th1 and Th2 cell immune responses to protect adenoviral hDPP4-transducted mice from MERS-CoV challenge (66).

However, it is known that pre-existing immunity to prevalent adenovirus serotypes can inhibit the efficacy of adenovirus-vectored vaccines $(127,128)$. Therefore, exploring other AdV types as vectors has become a possible solution. The simian adenovirus is an alternative choice for a vector because of minimal pre-existing immunity in humans, except for the Africans (129). The replication-deficient chimpanzee adenoviruses ChAdOx1 and AdC68 $(66,130)$ expressing MERS-CoV proteins significantly reduced clinical signs in camels (67), induced sustained and high levels of neutralizing antibodies and $\mathrm{T}$ cell responses in mice (70), and protected mice against lethal challenge (68). A phase II clinical trial is now underway. 


\section{SARS-CoV-2 Vaccines}

The vaccine candidate AZD1222 is based on ChAdOx1 (a MERS$\mathrm{CoV}$ vaccine mentioned above), and utilizes a replication-deficient chimpanzee adenovirus vector. This entered phase II/III clinical trials in the UK and India in May 2020, and phase III trials in Brazil, South Africa, and the United States. It was developed by Consortium of the Jenner Institute/Astrazeneca/University of Oxford. In their phase I/II, single-blind, randomized controlled trial, spike-specific T-cell responses peaked on day 14, and antispike IgG responses rose by day 28 , while neutralizing antibodies were shown in all participants after a booster dose. Adverse reactions were significantly reduced by use of prophylactic paracetamol (131).

However, in September, the phase III trial was halted because one volunteer developed transverse myelitis. On October 21, it was reported that that a volunteer in Brazil who once worked in a hospital and had received a dose of placebo in the trial, died of COVID-19 (https://www.nytimes.com/live/2020/10/21/world/ covid-19-coronavirus-updates/a-vaccine-trial-volunteer-inbrazil-has-died-but-health-authorities-say-the-vaccine-was-notto-blame). However the trial was soon restarted. The safety of the chimpanzee adenovirus vectored SARS-CoV-2 vaccine will be closely monitored going forward.

In China, human adenovirus type 5 vectored COVID-19 vaccine (Ad5-nCoV) developed by Cansino Biologics/Beijing Institute of Biotechnology entered phase I trials in early March and phase II trials in April. phase III trials began in August, 2020. The vaccine was approved for China military use on June 25, 2020, which was the first approved COVID-19 vaccine for limited use. Most adverse reactions reported in all dose groups were mild or moderate in severity. No serious adverse event was noted within 28 days post-vaccination. The vaccine showed immunogenicity and tolerance 28 days after the first inoculation. Neutralizing antibodies peaked at day 28 postvaccination, and specific T-cell response peaked at day 14 (132). In a phase II clinical trial in 508 participants, the Ad5-vectored COVID19 vaccine given at $5 \times 10^{10}$ viral particles showed safety and induced significant immune responses in the majority of recipients after a single immunization (133). The vaccine will be studied in a phase III trial in Saudi Arabia and Russia (https:/www.arabnews.com/node/ 1717041/saudi-arabia; https://www.sohu.com/a/414125695_115479). Another HAdV-5 vectored COVID-19 vaccine candidate developed by a Chinese research group also conferred protection from SARS$\mathrm{CoV}-2$ challenge in rhesus macaques with a single vaccination either intramuscularly or intranasally (134).

On October 8th, China officially joined the COVAX, a global COVID-19 vaccine allocation plan co-led by the World Health Organization (WHO) that aims to help purchase and fairly distribute COVID-19 vaccines (https://www.weforum.org/ agenda/2020/09/covax-who-cepi-gavi-covid-19-coronavirusvaccines-distribution/). CanSino Biologics announced a supply agreement of 35 million doses of COVID-19 vaccine for Mexico from the end of 2020 through the year 2021. Compared with other vaccines developed by Pfizer, AstraZeneca, Covax, the Ad5-nCoV vaccine of CanSino Biologics is the only single-dose regime candidate (http://www.cansinotech.com/html/1///179/ 180/556.html).
The other approved COVID-19 vaccine is developed by Gamaleya Research Institute of Russia. The first dose contains HAdV-26 vectored vaccine, based on an uncommon adenovirus type. The booster dose is composed of HAdV-5 vectored vaccine, similar to the one being developed by CanSino, China. The phase I trial began in June 2020. Phase $1 / 2$ non-randomized studies of a heterologous prime-boost COVID-19 vaccine based on rAd26-S and rAd5-S showed that the vaccine was safe and well tolerated. Cellular immunity, neutralizing antibodies, and RBD specific IgG were detected in all participants, and no severe adverse reactions were reported after vaccination (135). Named Sputnik-V, this vaccine received early approval for use in Russia in August 2020 without completing a phase III trial (https://www.nature.com/ articles/d41586-020-02386-2). On October 14, 2020, Russia granted regulatory approval to a second COVID-19 vaccine, even though the vaccine had yet to begin large scale phase-III trials. This was only two months after approval of their first vaccine. Experts expressed caution due to a lack of safety and efficacy data (https://www.webmd.com/lung/news/20200908/ russia-begins-rollout-of-covid-19-vaccine). Due to the incomplete completion of phase III clinical trials, the safety of these vaccine candidates is expected to be evaluated with special scrutiny (https://www.usnews.com/news/world/articles/2020-0820/un-discussions-with-russia-on-covid-19-vaccine-under-way).

Another HAdV-26 vectored vaccine is developed by Janssen Pharmaceutical Companies of Johnson \& Johnson. In the phase I/II clinical trial, the vaccine JNJ-78436735 induced robust humoral and cellular immune responses in middle-age adults and the elderly (136). On September 23, 2020, Johnson \& Johnson announced the launch of its large-scale, pivotal, multicountry phase III trial(named ENSEMBLE) for its COVID-19 vaccine candidate. This study enrolled up to 60,000 adults 18 years old and older, including participants over 60 years old, and those both with and without comorbidities associated with an increased risk for progression to severe COVID-19 (https://www. jnj.com/johnson-johnson-initiates-pivotal-global-phase-3clinical-trial-of-janssens-covid-19-vaccine-candidate).

It is optimized that the type of adenovirus vectors used in the boost dose is different from that in the initial immunization. In theory, the alternate use of human and simian adenovirus vectors in the immunization steps is better than the use of the same type of adenovirus vectors. Additionally, the grouping of participants with high and low levels of pre-existing immunity against the adenovirus vectors should be considered.

\section{MVA Vectored Vaccines SARS-CoV Vaccines}

Modified vaccinia virus Ankara (MVA) is replication-defective and used for viral antigen expression in mammalian cells. MVA stimulates inflammatory cytokines and chemokines and migration of lymphocytes and monocytes, making it advantageous in vaccine applications. MVA-SARS-CoV produced effective neutralizing antibodies with high immunogenicity in mice, rabbits, and monkeys, and protected against challenge in mice (29-32). 


\section{MERS-CoV Vaccines}

MVA-MERS-S protein vaccines induced neutralizing antibodies and $\mathrm{CD} 8{ }^{+} \mathrm{T}$ cell responses (62) and prevented tissue damage in AdV-hDPP4 transgenic mice (63). Likewise, intramuscular administration of MVA-MERS-CoV induced neutralizing antibodies in dromedary camels and limited virus replication, resulting in effective immune protection (64).

\section{SARS-CoV-2 Vaccines}

There are five MVA vectored SARS-CoV-2 vaccines under development. Among them, the spike gene vaccine developed by German Center for Infection Research is registered in a phase I trial. The vaccine is expected to be ready for approval by the end of 2021.

\section{Other Virus Vector Vaccines SARS-CoV Vaccines}

Although the immunity of Measles virus (MV) vector among humans may be an obstacle for its application, the SARS-CoV S protein expressed by the MV vector induced high neutralizing antibodies and Th1 cell immune responses in susceptible mice, along with effective protection from challenge. Similarly, a recombinant Venezuelan equine encephalitis virus (VEE)SARS-CoV vaccine elicited high IgG titers in mice while retaining wild-type VEE replication ability $(36,37,137)$. The use of MV and VEE as viral vectors for $\mathrm{CoV}$ vaccines may yet have potential.

\section{MERS-CoV Vaccines}

A single dose of parainfluenza virus 5 (PIV5)-based vaccine expressing the MERS-CoV S protein induced neutralizing antibodies and robust $\mathrm{T}$ cell responses in hDPP4 mice. A single-dose intranasal immunization brought stronger protection than single-dose intramuscular immunization. Mice immunized with PIV5-MERS-S protein developed greater mononuclear cell infiltration and less pathological changes in infected lungs (including edema, hyaline membranes, necrotic cellular debris, etc.), as well as complete protection against a lethal challenge against MERS-CoV and lower viral titers. Compared to inactivated MERS-CoV, histopathological changes in lungs such as hyaline membrane formation and hypersensitivity-type response with perivascular eosinophilic infiltration were milder (138).

\section{SARS-CoV-2 Vaccines}

In 2019, researchers at the University of Hong Kong and Xiamen University developed a nasal-spray vaccine for the flu based on a genetically weakened influenza virus. Earlier this year, they engineered the same vaccine to produce coronavirus spike protein. On September 9, they received approval to start clinical trials (https://www.hku.hk/press/news_detail_21583.html).

Merck has developed a SARS-CoV-2 vaccine originally developed at Institute Pasteur using a weakened measles virus that carries the coronavirus spike gene. They launched phase I trials in August (https://clinicaltrials.gov/ct2/show/NCT04497298?term= vaccine \&cond=covid-19\&draw=2\&rank=1).

In addition, the intranasal vaccine candidate (MV-012-968) expressing SARS-CoV-2 S protein based on an RSV vector was developed by Meissa. It showed robust immune responses in rats and in healthy adults, and is currently in phase I trials in healthy adults and young children (https://www.biospace.com/article/ another-covid-19-vaccine-joins-the-race-this-time-it-s-a-liveweakened-virus/?tdsourcetag=s_pctim_aiomsg).

A SARS-CoV-2 S gene vaccine based on adeno-associated virus was developed by the Massachusetts Eye and Ear, Massachusetts General Hospital and the University of Pennsylvania. Phase I trials are set to begin in late 2020.

\section{ANTIBODY-DEPENDENT ENHANCEMENT (ADE)}

$\mathrm{ADE}$ is an adverse reaction in which non-neutralizing antibodies produced following virus infection or a vaccination enhance the infectivity of a subsequent virus infection (139). It is a mechanism found to play a role in infection by dengue viruses, $\mathrm{HIV}$, influenza virus, Ebola virus, feline coronavirus, and in SARS-CoV, which facilitates the infection of host target cells by anti-viral humoral immune responses. ADE can be mediated by antibody Fc receptor-associated internalization of the virus, resulting in greater viral replication and cytokine release in the presence of virus-specific antibodies (74). ADE may occur especially when the antibody levels are relatively lower.

It was reported that SARS-CoV used ADE to enhance the infectivity of human promonocytes. Increased TNF- $\alpha$, IL-4, and IL-6 were detected in human promonocytes isolated from a leukemia patient (HL-CZ cells) infected with SARS-CoV, and treatment with highly diluted anti-sera against SARS$\mathrm{CoV}$ was associated with higher levels of virus infection in cells and increased cytopathic effect (CPE) (140). Moreover, S protein specific-IgG may have promoted proinflammatory cytokine production through FcyRI and/or Fc $\gamma$ RIIA, suggesting a potential role of Fc $\gamma$ Rs for the postulated reprogramming of alternatively activated macrophages. Blockade of FcyRs reduced proinflammatory cytokine production and lung injury (19).

To date, no ADE has been observed in MERS-CoV and SARS-CoV-2. However, due to the taxonomic and structural similarities between SARS-CoV, MERS-CoV, and SARSCOV-2, ADE is an issue that should be considered seriously in designing MERS-CoV and SARS-CoV-2 vaccines, particularly those with a full-length $S$ protein. Neutralizing epitopes could elicit a more robust protective immunity but less or no ADE side-effects. Recent studies have found that MERS-CoV vaccine candidates based on a shorter S1 domain or shorter RBD induce stronger immune responses than those based on the full-length S protein $(48,141)$. Whether the ADE is common during all coronavirus infections needs further study and verification. 


\section{DISCUSSION}

From the SARS epidemic 17 years ago to the MERS-CoV epidemic in 2012, and the COVID-19 pandemic caused by the newly emerged SARS-CoV-2 in December 2019, the threat of future severe acute respiratory diseases due to the CoV family cannot be underestimated. Clinical trials of SARS-CoV vaccines were terminated due to the disappearance of SARS-CoV and the lack of potential patients. The MERS-CoV vaccine completed only phase I clinical trials in humans. The shared experiences in developing SARS-CoV and MERS-CoV vaccines may provide a reference for COVID-19 vaccine development.

Currently, the many different SARS-CoV-2 vaccines are in different stages of development around the world. Different types being tested include recombinant protein subunit vaccines, nucleic acid vaccines, viral vector vaccines, inactivated viruses, and live attenuated vaccines. Among the 212 vaccines being developed, three inactivated vaccines, 4 non-replicating viral vector vaccines, two protein subunit vaccines and two RNA vaccines have entered phase III clinical trials. One human adenovirus vector vaccine and three inactivated vaccines have been approved for limited use in China. In Russia, one adenovirus vector vaccine and one peptide vaccine have been approved for early use. The mRNA vaccine of Moderna, HAdV5 vector vaccine of CanSino Biologics, inactivated vaccines of Sinopharm, Wuhan Institute of Biological Products, and Sinovac Biotech have all entered phase III clinical trials. The mRNA vaccine of BioNTech, Germany, and the Chimpanzee adenovirus vector vaccine of AstraZeneca and the University of Oxford have entered phase II/III clinical trials (Table 3). Together, these represent the most promising and earliest candidate vaccines against COVID-19.

There remain numerous unknowns for all the current vaccine candidates. For examples, will the vaccine provide effective protection in immune deficient or dysfunctional patients and the elderly, and for how long will it provide immunity? Recently, HKU researchers have confirmed the world's first case of reinfection by the SARS-CoV-2 (https://www.sciencenews.org/ article/coronavirus-covid-19-first-case-reinfection-man-hongkong), in which reinfection occurred after just a few months from the first infection. SARS-CoV-2 may persist as a source of human infections as is the case for other common-cold associated human coronaviruses, even if patients have acquired some level of immunity via natural infection. If the immunity to SARS-CoV-2 can disappear after natural infection, vaccination should also be considered for those persons with prior infection. Additionally, the combined use of nucleic acid vaccines, subunit vaccines, inactivated vaccines, and viral vector vaccines with nanoparticle technology or adjuvants, and multiple vaccinations of COVID-19 should be considered if immunity wanes over time.

There is consensus that the engagement of the S1 RBD with its receptor destabilizes the trimer (prefusion state), triggering the shedding of the S1 units, which allows a remarkable conformational change in the spike from a large club-shaped structure into a thin and long nail-like structure (postfusion state). $\beta$-propiolactone is the chemical inactivating agent successfully used in rabies and other vaccines, and $\beta$ propiolactone-treated SARS-CoV-2 viruses exhibit most of their spikes in the postfusion conformation (142). Most COVID-19 vaccine candidates rely on the $S$ protein as their antigen, since this is the primary exposed protein on the surface of the SARS-CoV-2 viral particle, and $\beta$-propiolactone is used as the inactivation reagent. However, there is the unfortunate example of the formalin-inactivated respiratory syncytial virus (FI-RSV) vaccine trial of the 1960 s, which led to enhancement of disease symptoms in vaccinated children after natural exposure to RSV, with two fatal cases (143). Structural studies revealed that one contributing factor to the vaccine failure was that the prefusion state of the RSV spike was absent and the postfusion state was primarily represented in the FI-RSV vaccine formula (144). Therefore, the inactivated SARS-CoV-2 vaccines may not be the safest, and there is need to confirm the $S$ protein state.

It is well known that RNA viruses have much higher mutation rates than DNA viruses. More and more mutations in the spike protein of SARS-CoV-2 are being continuously reported (145, 146), e.g., the most dominant variant D614G in spike protein $(146,147)$ and V367F in RBD (145), which may increase viral infectivity. As the spike protein of coronaviruses is a major target for vaccines, neutralizing antibodies, and viral entry inhibitors, spike protein mutations in circulating viral strains may affect the effectiveness of a vaccine. Therefore, it is very important to determine whether the neutralizing capacity of vaccine-induced neutralizing antibodies remain unchanged in clinical trials over time.

While clinical treatment strategies have been optimized to save lives and improve prognosis, a safe and effective vaccine would have far-reaching public health significance for controlling and stopping the COVID-19 pandemic. Clinical trials are indispensable to determine the safety and effectiveness of COVID-19 vaccines, and will also need to evolve to include children, the elderly, pregnant women, and people with underlying medical conditions.

\section{AUTHOR CONTRIBUTIONS}

QZ conceptualized the idea for the review. JZhao, SZ, JO, JZhang, WL, WG, XW, and YY performed the literature search, analyzed cited references, and wrote the original article. WZ, JW, JC and QZ critically revised the article. All authors contributed to the article and approved the submitted version.

\section{FUNDING}

This work was supported by grants from the National Key Research and Development Program of China (2018YFE0204503) and Natural Science Foundation of Guangdong Province (2018B030312010), as well as the Guangzhou Healthcare Collaborative Innovation Major Project (201803040004 and 201803040007). 


\section{REFERENCES}

1. Cui J, Li F, Shi ZL. Origin and evolution of pathogenic coronaviruses. Nat Rev Microbiol (2019) 17(3):181-92. doi: 10.1038/s41579-018-0118-9

2. Ruch TR, Machamer CE. The coronavirus E protein: assembly and beyond. Viruses (2012) 4(3):363-82. doi: 10.3390/v4030363

3. Schoeman D, Fielding BC. Coronavirus envelope protein: current knowledge. Virol J (2019) 16(1):69. doi: 10.1186/s12985-019-1182-0

4. WHO. Coronavirus disease (COVID-2019) situation reports. https://www. who.int/emergencies/diseases/novel-coronavirus-2019/situation-reports/.

5. Zhou P, Yang X-L, Wang X-G, Hu B, Zhang L, Zhang W, et al. Discovery of a novel coronavirus associated with the recent pneumonia outbreak in humans and its potential bat origin. Nature (2020) 579(7798):270-3. doi: 10.1101/2020.01.22.914952

6. Wu A, Peng Y, Huang B, Ding X, Wang X, Niu P, et al. Genome Composition and Divergence of the Novel Coronavirus (2019-nCoV) Originating in China. Cell Host Microbe (2020) 27(3):325-8. doi: 10.1016/ j.chom.2020.02.001

7. Chen WH, Chag SM, Poongavanam MV, Biter AB, Ewere EA, Rezende W, et al. Optimization of the Production Process and Characterization of the Yeast-Expressed SARS-CoV Recombinant Receptor-Binding Domain (RBD219-N1), a SARS Vaccine Candidate. J Pharm Sci (2017) 106 (8):1961-70. doi: 10.1016/j.xphs.2017.04.037

8. Chen WH, Du L, Chag SM, Ma C, Tricoche N, Tao X, et al. Yeast-expressed recombinant protein of the receptor-binding domain in SARS-CoV spike protein with deglycosylated forms as a SARS vaccine candidate. Hum Vaccin Immunother (2014) 10(3):648-58. doi: 10.4161/hv.27464

9. Zakhartchouk AN, Sharon C, Satkunarajah M, Auperin T, Viswanathan S, Mutwiri G, et al. Immunogenicity of a receptor-binding domain of SARS coronavirus spike protein in mice: implications for a subunit vaccine. Vaccine (2007) 25(1):136-43. doi: 10.1016/j.vaccine.2006.06.084

10. Du L, Zhao G, He Y, Guo Y, Zheng B-J, Jiang S, et al. Receptor-binding domain of SARS-CoV spike protein induces long-term protective immunity in an animal model. Vaccine (2007) 25(15):2832-8. doi: 10.1016/ j.vaccine.2006.10.031

11. Du L, Zhao G, Chan CCS, Li L, He Y, Zhou Y, et al. A 219-mer CHOExpressing Receptor-Binding Domain of SARS-CoV S Protein Induces Potent Immune Responses and Protective Immunity. Viral Immunol (2010) 23(2):211-9. doi: 10.1089/vim.2009.0090

12. Guo X, Guo Z, Duan C, Chen Z, Wang G, Lu Y, et al. Long-Term Persistence of IgG Antibodies in SARS-CoV Infected Healthcare Workers. medRxiv [Preprint] (2020) 2020.02.12.20021386. doi: 10.1101/2020.02.12.20021386

13. Li Z, Palaniyandi S, Zeng R, Tuo W, Roopenian DC, Zhu X. Transfer of IgG in the female genital tract by MHC class I-related neonatal Fc receptor (FcRn) confers protective immunity to vaginal infection. Proc Natl Acad Sci U States America (2011) 108(11):4388-93. doi: 10.1073/pnas.1012861108

14. Ng O-W, Chia A, Tan AT, Jadi RS, Leong HN, Bertoletti A, et al. Memory $\mathrm{T}$ cell responses targeting the SARS coronavirus persist up to 11 years post-infection. Vaccine (2016) 34(17):2008-14. doi: 10.1016/ j.vaccine.2016.02.063

15. Zhang M-Y, Wang Y, Mankowski MK, Ptak RG, Dimitrov DS. Crossreactive HIV-1-neutralizing activity of serum IgG from a rabbit immunized with gp41 fused to IgG1 Fc: possible role of the prolonged half-life of the immunogen. Vaccine (2009) 27(6):857-63. doi: 10.1016/j.vaccine. 2008.11.083

16. Zhao J, Zhao J, Mangalam AK, Channappanavar R, Fett C, Meyerholz DK, et al. Airway Memory CD4(+) T Cells Mediate Protective Immunity against Emerging Respiratory Coronaviruses. Immunity (2016) 44(6):1379-91. doi: 10.1016/j.immuni.2016.05.006

17. Enjuanes SL, Almazan F. inventors; Vaccine against severe accute respiratory syndrome causing coronavirus (SARS-CoV). International Application No. PCT/EP2005/009478 (2006).

18. Zhang L, Zhang F, Yu W, He T, Yu J, Yi CE, et al. Antibody responses against SARS coronavirus are correlated with disease outcome of infected individuals. J Med Virol (2006) 78(1):1-8. doi: 10.1002/jmv.20499

19. Liu L, Wei Q, Lin Q, Fang J, Wang H, Kwok H, et al. Anti-spike IgG causes severe acute lung injury by skewing macrophage responses during acute
SARS-CoV infection. JCI Insight (2019) 4(4):e123158. doi: 10.1172/ jci.insight. 123158

20. Bright RA, Carter DM, Crevar CJ, Toapanta FR, Steckbeck JD, Cole KS, et al. Cross-clade protective immune responses to influenza viruses with H5N1 HA and NA elicited by an influenza virus-like particle. PloS One (2008) 3(1): e1501. doi: 10.1371/journal.pone.0001501

21. Bright RA, Carter DM, Daniluk S, Toapanta FR, Ahmad A, Gavrilov V, et al. Influenza virus-like particles elicit broader immune responses than whole virion inactivated influenza virus or recombinant hemagglutinin. Vaccine (2007) 25(19):3871-8. doi: 10.1016/j.vaccine.2007.01.106

22. Lokugamage KG, Yoshikawa-Iwata N, Ito N, Watts DM, Wyde PR, Wang N, et al. Chimeric coronavirus-like particles carrying severe acute respiratory syndrome coronavirus ( $\mathrm{SCoV}$ ) $\mathrm{S}$ protein protect mice against challenge with SCoV. Vaccine (2008) 26(6):797-808. doi: 10.1016/j.vaccine.2007.11.092

23. Lan J, Deng Y, Song J, Huang B, Wang W, Tan W. Significant Spike-Specific IgG and Neutralizing Antibodies in Mice Induced by a Novel Chimeric Virus-Like Particle Vaccine Candidate for Middle East Respiratory Syndrome Coronavirus. Virol Sin (2018) 33(5):453-5. doi: 10.1007/ s12250-018-0064-8

24. Liu MA. DNA vaccines: an historical perspective and view to the future. Immunol Rev (2011) 239(1):62-84. doi: 10.1111/j.1600-065X.2010.00980.x

25. Huang Y, Yang Z-y, Kong W-p, Nabel GJ. Generation of Synthetic Severe Acute Respiratory Syndrome Coronavirus Pseudoparticles: Implications for Assembly and Vaccine Production. J Virol (2004) 78(22):12557-65. doi: 10.1128/JVI.78.22.12557-12565.2004\%JJournalofVirology

26. Zhao P, Ke J-S, Qin Z-L, Ren H, Zhao L-J, Yu J-G, et al. DNA vaccine of SARS-Cov $S$ gene induces antibody response in mice. Acta Biochim Biophys $\operatorname{Sin}(2004)$ 36(1):37-41. doi: 10.1093/abbs/36.1.37

27. Huang J, Ma R. Wu C-y. Immunization with SARS-CoV S DNA vaccine generates memory $\mathrm{CD} 4+$ and $\mathrm{CD} 8+\mathrm{T}$ cell immune responses. Vaccine (2006) 24(23):4905-13. doi: 10.1016/j.vaccine.2006.03.058

28. Raghuwanshi D, Mishra V, Das D, Kaur K, Suresh MR. Dendritic cell targeted chitosan nanoparticles for nasal DNA immunization against SARS CoV nucleocapsid protein. Mol Pharmaceut (2012) 9(4):946-56. doi: $10.1021 / \mathrm{mp} 200553 \mathrm{x}$

29. Delaloye J, Roger T, Steiner-Tardivel Q-G, Le Roy D, Knaup Reymond M, Akira $\mathrm{S}$, et al. Innate immune sensing of modified vaccinia virus Ankara (MVA) is mediated by TLR2-TLR6, MDA-5 and the NALP3 inflammasome. PloS Pathog (2009) 5(6):e1000480. doi: 10.1371/journal.ppat.1000480

30. Lehmann MH, Kastenmuller W, Kandemir JD, Brandt F, Suezer Y, Sutter G. Modified vaccinia virus ankara triggers chemotaxis of monocytes and early respiratory immigration of leukocytes by induction of CCL2 expression. J Virol (2009) 83(6):2540-52. doi: 10.1128/JVI.01884-08

31. Bisht H, Roberts A, Vogel L, Bukreyev A, Collins PL, Murphy BR, et al. Severe acute respiratory syndrome coronavirus spike protein expressed by attenuated vaccinia virus protectively immunizes mice. Proc Natl Acad Sci U States America (2004) 101(17):6641-6. doi: 10.1073/pnas.0401939101

32. Chen Z, Zhang L, Qin C, Ba L, Yi CE, Zhang F, et al. Recombinant modified vaccinia virus Ankara expressing the spike glycoprotein of severe acute respiratory syndrome coronavirus induces protective neutralizing antibodies primarily targeting the receptor binding region. J Virol (2005) 79(5):267888. doi: 10.1128/JVI.79.5.2678-2688.2005

33. Guo X, Deng Y, Chen H, Lan J, Wang W, Zou X, et al. Systemic and mucosal immunity in mice elicited by a single immunization with human adenovirus type 5 or 41 vector-based vaccines carrying the spike protein of Middle East respiratory syndrome coronavirus. Immunology (2015) 145(4):476-84. doi: $10.1111 /$ imm. 12462

34. Kim E, Okada K, Kenniston T, Raj VS, AlHajri MM, Farag EABA, et al. Immunogenicity of an adenoviral-based Middle East Respiratory Syndrome coronavirus vaccine in BALB/c mice. Vaccine (2014) 32(45):5975-82. doi: $10.1016 /$ j.vaccine.2014.08.058

35. Shim B-S, Stadler K, Nguyen HH, Yun C-H, Kim DW, Chang J, et al. Sublingual immunization with recombinant adenovirus encoding SARS-CoV spike protein induces systemic and mucosal immunity without redirection of the virus to the brain. Virol J (2012) 9:215. doi: 10.1186/1743-422X-9-215

36. Escriou N, Callendret B, Lorin V, Combredet C, Marianneau P, Février M, et al. Protection from SARS coronavirus conferred by live measles vaccine 
expressing the spike glycoprotein. Virology (2014) 452-453:32-41. doi: 10.1016/j.virol.2014.01.002

37. Agnihothram S, Menachery VD, Yount BL, Lindesmith LC, Scobey T, Whitmore A, et al. Development of a Broadly Accessible Venezuelan Equine Encephalitis Virus Replicon Particle Vaccine Platform. J Virol (2018), 92(11):e00027-18. doi: 10.1128/JVI.00027-18

38. Honda-Okubo Y, Barnard D, Ong CH, Peng B-H, Tseng C-TK, Petrovsky N. Severe acute respiratory syndrome-associated coronavirus vaccines formulated with delta inulin adjuvants provide enhanced protection while ameliorating lung eosinophilic immunopathology. J Virol (2015) 89 (6):2995-3007. doi: 10.1128/JVI.02980-14

39. Iwata-Yoshikawa N, Uda A, Suzuki T, Tsunetsugu-Yokota Y, Sato Y, Morikawa S, et al. Effects of Toll-like receptor stimulation on eosinophilic infiltration in lungs of $\mathrm{BALB} / \mathrm{c}$ mice immunized with $\mathrm{UV}$-inactivated severe acute respiratory syndrome-related coronavirus vaccine. J Virol (2014) 88 (15):8597-614. doi: 10.1128/JVI.00983-14

40. Zhou J, Wang W, Zhong Q, Hou W, Yang Z, Xiao S-Y, et al. Immunogenicity, safety, and protective efficacy of an inactivated SARSassociated coronavirus vaccine in rhesus monkeys. Vaccine (2005) 23 (24):3202-9. doi: 10.1016/j.vaccine.2004.11.075

41. Lamirande EW, DeDiego ML, Roberts A, Jackson JP, Alvarez E, Sheahan T, et al. A live attenuated severe acute respiratory syndrome coronavirus is immunogenic and efficacious in golden Syrian hamsters. J Virol (2008) 82 (15):7721-4. doi: 10.1128/JVI.00304-08

42. Fett C, DeDiego ML, Regla-Nava JA, Enjuanes L, Perlman S. Complete protection against severe acute respiratory syndrome coronavirus-mediated lethal respiratory disease in aged mice by immunization with a mouseadapted virus lacking E protein. J Virol (2013) 87(12):6551-9. doi: 10.1128/ JVI.00087-13

43. Jimenez-Guardeño JM, Regla-Nava JA, Nieto-Torres JL, DeDiego ML, Castaño-Rodriguez C, Fernandez-Delgado R, et al. Identification of the Mechanisms Causing Reversion to Virulence in an Attenuated SARS-CoV for the Design of a Genetically Stable Vaccine. PloS Pathog (2015) 11(10): e1005215. doi: 10.1371/journal.ppat.1005215

44. Menachery VD, Yount BL, Josset L, Gralinski LE, Scobey T, Agnihothram S, et al. Attenuation and restoration of severe acute respiratory syndrome coronavirus mutant lacking 2'-o-methyltransferase activity. J Virol (2014) 88 (8):4251-64. doi: 10.1128/JVI.03571-13

45. Becares M, Pascual-Iglesias A, Nogales A, Sola I, Enjuanes L, Zuñiga S. Mutagenesis of Coronavirus nsp14 Reveals Its Potential Role in Modulation of the Innate Immune Response. J Virol (2016) 90(11):5399-414. doi: 10.1128/JVI.03259-15

46. Graham RL, Becker MM, Eckerle LD, Bolles M, Denison MR, live BRSA. impaired-fidelity coronavirus vaccine protects in an aged, immunocompromised mouse model of lethal disease. Nat Med (2012) 18 (12):1820-6. doi: 10.1038/nm.2972

47. Choi J, Kim M-G, Oh Y-K, Kim YB. Progress of Middle East respiratory syndrome coronavirus vaccines: a patent review. Expert Opin Ther Patents (2017) 27(6):721-31. doi: 10.1080/13543776.2017.1281248

48. Okba NM, Raj VS, Haagmans BL. Middle East respiratory syndrome coronavirus vaccines: current status and novel approaches. Curr Opin Virol (2017) 23:49-58. doi: 10.1016/j.coviro.2017.03.007

49. Zhang N, Channappanavar R, Ma C, Wang L, Tang J, Garron T, et al. Identification of an ideal adjuvant for receptor-binding domain-based subunit vaccines against Middle East respiratory syndrome coronavirus. Cell Mol Immunol (2016) 13(2):180-90. doi: 10.1038/cmi.2015.03

50. Tai W, Zhao G, Sun S, Guo Y, Wang Y, Tao X, et al. A recombinant receptorbinding domain of MERS-CoV in trimeric form protects human dipeptidyl peptidase 4 (hDPP4) transgenic mice from MERS-CoV infection. Virology (2016) 499:375-82. doi: 10.1016/j.virol.2016.10.005

51. Smith G, Liu Y, Massare M. inventors; Immunogenic middle east respiratory syndrome coronavirus (mers-cov) compositions and methods. United States patent US 11201601423S (2015).

52. Pallesen J, Wang N, Corbett KS, Wrapp D, Kirchdoerfer RN, Turner HL, et al. Immunogenicity and structures of a rationally designed prefusion MERS-CoV spike antigen. Proc Natl Acad Sci U States America (2017) 114 (35):E7348-E57. doi: 10.1073/pnas.1707304114
53. Jiaming L, Yanfeng Y, Yao D, Yawei H, Linlin B, Baoying H, et al. The recombinant $\mathrm{N}$-terminal domain of spike proteins is a potential vaccine against Middle East respiratory syndrome coronavirus (MERS-CoV) infection. Vaccine (2017) 35(1):10-8. doi: 10.1016/j.vaccine.2016.11.064

54. Wang N, Rosen O, Wang L, Turner HL, Stevens LJ, Corbett KS, et al. Structural Definition of a Neutralization-Sensitive Epitope on the MERSCoV S1-NTD. Cell Rep (2019) 28(13):3395-405.e6. doi: 10.1016/ j.celrep.2019.08.052

55. Li E, Chi H, Huang P, Yan F, Zhang Y, Liu C, et al. A Novel Bacterium-Like Particle Vaccine Displaying the MERS-CoV Receptor-Binding Domain Induces Specific Mucosal and Systemic Immune Responses in Mice. Viruses (2019) 11(9):799. doi: 10.3390/v11090799

56. Muthumani K, Falzarano D, Reuschel EL, Tingey C, Flingai S, Villarreal DO, et al. A synthetic consensus anti-spike protein DNA vaccine induces protective immunity against Middle East respiratory syndrome coronavirus in nonhuman primates. Sci Trans Med (2015) 7(301):301ra132. doi: 10.1126/ scitranslmed.aac7462

57. Modjarrad K, Roberts CC, Mills KT, Castellano AR, Paolino K, Muthumani K, et al. Safety and immunogenicity of an anti-Middle East respiratory syndrome coronavirus DNA vaccine: a phase 1, open-label, single-arm, dose-escalation trial. Lancet Infect Dis (2019) 19(9):1013-22. doi: 10.1016/S1473-3099(19) 30266-X

58. Wang L, Shi W, Joyce MG, Modjarrad K, Zhang Y, Leung K, et al. Evaluation of candidate vaccine approaches for MERS-CoV. Nat Commun (2015) 6:7712. doi: $10.1038 /$ ncomms 8712

59. Cayabyab MJ, Kashino SS, Campos-Neto A. Robust immune response elicited by a novel and unique Mycobacterium tuberculosis protein using an optimized DNA/protein heterologous prime/boost protocol. Immunology (2012) 135(3):216-25. doi: 10.1111/j.1365-2567.2011.03525.x

60. Chi $\mathrm{H}$, Zheng $\mathrm{X}$, Wang $\mathrm{X}$, Wang $\mathrm{C}$, Wang $\mathrm{H}$, Gai W, et al. DNA vaccine encoding Middle East respiratory syndrome coronavirus S1 protein induces protective immune responses in mice. Vaccine (2017) 35(16):2069-75. doi: 10.1016/j.vaccine.2017.02.063

61. Al-Amri SS, Abbas AT, Siddiq LA, Alghamdi A, Sanki MA, Al-Muhanna MK, et al. Immunogenicity of Candidate MERS-CoV DNA Vaccines Based on the Spike Protein. Sci Rep (2017) 7:44875. doi: 10.1038/srep44875

62. Song F, Fux R, Provacia LB, Volz A, Eickmann M, Becker S, et al. Middle East respiratory syndrome coronavirus spike protein delivered by modified vaccinia virus Ankara efficiently induces virus-neutralizing antibodies. J Virol (2013) 87(21):11950-4. doi: 10.1128/JVI.01672-13

63. Volz A, Kupke A, Song F, Jany S, Fux R, Shams-Eldin H, et al. Protective Efficacy of Recombinant Modified Vaccinia Virus Ankara Delivering Middle East Respiratory Syndrome Coronavirus Spike Glycoprotein. J Virol (2015) 89(16):8651-6. doi: 10.1128/JVI.00614-15

64. Haagmans BL, van den Brand JMA, Raj VS, Volz A, Wohlsein P, Smits SL, et al. An orthopoxvirus-based vaccine reduces virus excretion after MERSCoV infection in dromedary camels. Sci (N Y NY) (6268) 2016) 351:77-81. doi: $10.1126 /$ science.aad 1283

65. Koch T, Dahlke C, Fathi A, Kupke A, Krähling V, Okba NMA, et al. Safety and immunogenicity of a modified vaccinia virus Ankara vector vaccine candidate for Middle East respiratory syndrome: an open-label, phase 1 trial. Lancet Infect Dis (2020) 20(7):827-38. doi: 10.1016/S1473-3099(20)30248-6

66. Jung S-Y, Kang KW, Lee E-Y, Seo D-W, Kim H-L, Kim H, et al. Heterologous prime-boost vaccination with adenoviral vector and protein nanoparticles induces both Th1 and Th2 responses against Middle East respiratory syndrome coronavirus. Vaccine (2018) 36(24):3468-76. doi: 10.1016/j.vaccine.2018.04.082

67. Alharbi NK, Qasim I, Almasoud A, Aljami HA, Alenazi MW, Alhafufi A, et al. Humoral Immunogenicity and Efficacy of a Single Dose of ChAdOx1 MERS Vaccine Candidate in Dromedary Camels. Sci Rep (2019) 9 (1):16292-. doi: 10.1038/s41598-019-52730-4

68. Munster VJ, Wells D, Lambe T, Wright D, Fischer RJ, Bushmaker T, et al. Protective efficacy of a novel simian adenovirus vaccine against lethal MERS$\mathrm{CoV}$ challenge in a transgenic human DPP4 mouse model. NPJ Vaccines (2017) 2:28. doi: 10.1038/s41541-017-0029-1

69. Alharbi NK, Padron-Regalado E, Thompson CP, Kupke A, Wells D, Sloan MA, et al. ChAdOx1 and MVA based vaccine candidates against MERS-CoV 
elicit neutralising antibodies and cellular immune responses in mice. Vaccine (2017) 35(30):3780-8. doi: 10.1016/j.vaccine.2017.05.032

70. Jia W, Channappanavar R, Zhang C, Li M, Zhou H, Zhang S, et al. Single intranasal immunization with chimpanzee adenovirus-based vaccine induces sustained and protective immunity against MERS-CoV infection. Emerg Microbes Infect (2019) 8(1):760-72. doi: 10.1080/22221751. 2019.1620083

71. Roberts A, Lamirande EW, Vogel L, Jackson JP, Paddock CD, Guarner J, et al. Animal models and vaccines for SARS-CoV infection. Virus Res (2008) 133(1):20-32. doi: 10.1016/j.virusres.2007.03.025

72. Tsunetsugu-Yokota Y, Ohnishi K, Takemori T. Severe acute respiratory syndrome (SARS) coronavirus: application of monoclonal antibodies and development of an effective vaccine. Rev Med Virol (2006) 16:117-131. doi: $10.1002 / \mathrm{rmv} .492$

73. Takasuka N, Fujii H, Takahashi Y, Kasai M, Morikawa S, Itamura S, et al. A subcutaneously injected UV-inactivated SARS coronavirus vaccine elicits systemic humoral immunity in mice. Int Immunol (2004) 16(10):1423-30. doi: $10.1093 /$ intimm/dxh143

74. Su S, Du L, Jiang S. Learning from the past: development of safe and effective COVID-19 vaccines. Nat Rev Microbiol (2020) 1-9. doi: 10.1038/s41579020-00462-y

75. Tsunetsugu-Yokota Y, Ato M, Takahashi Y, S-i H, Kaji T, Kuraoka M, et al. Formalin-treated UV-inactivated SARS coronavirus vaccine retains its immunogenicity and promotes Th2-type immune responses. Japanese J Infect Dis (2007) 60(2-3):106-12.

76. Bolles M, Deming D, Long K, Agnihothram S, Whitmore A, Ferris M, et al. A double-inactivated severe acute respiratory syndrome coronavirus vaccine provides incomplete protection in mice and induces increased eosinophilic proinflammatory pulmonary response upon challenge. J Virol (2011) 85 (23):12201-15. doi: 10.1128/JVI.06048-11

77. Agrawal AS, Tao X, Algaissi A, Garron T, Narayanan K, Peng B-H, et al. Immunization with inactivated Middle East Respiratory Syndrome coronavirus vaccine leads to lung immunopathology on challenge with live virus. Hum Vaccines Immunotherapeut (2016) 12(9):2351-6. doi: $10.1080 / 21645515.2016 .1177688$

78. Xia S, Duan K, Zhang Y, Zhao D, Zhang H, Xie Z, et al. Effect of an Inactivated Vaccine Against SARS-CoV-2 on Safety and Immunogenicity Outcomes: Interim Analysis of 2 Randomized Clinical Trials. JAMA (2020) 324(10):951-60. doi: 10.1001/jama.2020.15543

79. Gao Q, Bao L, Mao H, Wang L, Xu K, Yang M, et al. Development of an inactivated vaccine candidate for SARS-CoV-2. Sci (N Y NY) (2020) 369 (6499):77-81. doi: 10.1126/science.abc1932

80. Enjuanes L, Zuniga S, Castano-Rodriguez C, Gutierrez-Alvarez J, Canton J, Sola I. Molecular Basis of Coronavirus Virulence and Vaccine Development. Adv Virus Res (2016) 96:245-86. doi: 10.1016/bs.aivir.2016.08.003

81. DeDiego ML, Nieto-Torres JL, Jiménez-Guardeño JM, Regla-Nava JA, Alvarez E, Oliveros JC, et al. Severe acute respiratory syndrome coronavirus envelope protein regulates cell stress response and apoptosis. PloS Pathog (2011) 7(10):e1002315. doi: 10.1371/journal.ppat.1002315

82. DeDiego ML, Alvarez E, Almazán F, Rejas MT, Lamirande E, Roberts A, et al. A severe acute respiratory syndrome coronavirus that lacks the E gene is attenuated in vitro and in vivo. J Virol (2007) 81(4):1701-13. doi: 10.1128/ JVI.01467-06

83. Nieto-Torres JL, DeDiego ML, Verdiá-Báguena C, Jimenez-Guardeño JM, Regla-Nava JA, Fernandez-Delgado R, et al. Severe acute respiratory syndrome coronavirus envelope protein ion channel activity promotes virus fitness and pathogenesis. PloS Pathog (2014) 10(5):e1004077. doi: 10.1371/journal.ppat.1004077

84. Menachery VD, Gralinski LE, Mitchell HD, Dinnon KH, Leist SR, Yount BL, et al. Combination Attenuation Offers Strategy for Live Attenuated Coronavirus Vaccines. J Virol (2018) 92(17):e00710-18. doi: 10.1128/ jvi.00710-18

85. Bouvet M, Lugari A, Posthuma CC, Zevenhoven JC, Bernard S, Betzi S, et al. Coronavirus Nsp10, a critical co-factor for activation of multiple replicative enzymes. J Biol Chem (2014) 289(37):25783-96. doi: 10.1074/ jbc.M114.577353
86. Liu DX, Fung TS, Chong KK-L, Shukla A, Hilgenfeld R. Accessory proteins of SARS-CoV and other coronaviruses. Antiviral Res (2014) 109:97-109. doi: 10.1016/j.antiviral.2014.06.013

87. Almazán F, DeDiego ML, Sola I, Zuñiga S, Nieto-Torres JL, Marquez-Jurado S, et al. Engineering a replication-competent, propagation-defective Middle East respiratory syndrome coronavirus as a vaccine candidate. mBio (2013) 4(5): e00650-e13. doi: 10.1128/mBio.00650-13

88. Menachery VD, Gralinski LE, Mitchell HD, Dinnon KH, Leist SR, Yount BL, et al. Middle East Respiratory Syndrome Coronavirus Nonstructural Protein 16 Is Necessary for Interferon Resistance and Viral Pathogenesis. mSphere (2017) 2(6):e00346-17. doi: 10.1128/mSphere.00346-17

89. Mielech AM, Kilianski A, Baez-Santos YM, Mesecar AD, Baker SC. MERS$\mathrm{CoV}$ papain-like protease has deISGylating and deubiquitinating activities. Virology (2014) 450-451:64-70. doi: 10.1016/j.virol.2013.11.040

90. Hansson M, Nygren PA, Ståhl S. Design and production of recombinant subunit vaccines. Biotechnol Appl Biochem (2000) 32(2):95-107. doi: 10.1042/BA20000034

91. García A, De Sanctis JB. An overview of adjuvant formulations and delivery systems. APMIS Acta Pathol Microbiol Immunol Scandinavica (2014) 122 (4):257-67. doi: 10.1111/apm.12143

92. Du L, Tai W, Yang Y, Zhao G, Zhu Q, Sun S, et al. Introduction of neutralizing immunogenicity index to the rational design of MERS coronavirus subunit vaccines. Nat Commun (2016) 7:13473. doi: 10.1038/ ncomms 13473

93. Grifoni A, Sidney J, Zhang Y, Scheuermann RH, Peters B, Sette A. Candidate targets for immune responses to 2019-Novel Coronavirus (nCoV): sequence homology- and bioinformatic-based predictions. bioRxiv [Preprint] (2020) 2020.02.12.946087. doi: 10.1101/2020.02.12.946087

94. Keech C, Albert G, Cho I, Robertson A, Reed P, Neal S, et al. Phase 1-2 Trial of a SARS-CoV-2 Recombinant Spike Protein Nanoparticle Vaccine. New Engl J Med (2020) 383(24):2320-32. doi: 10.1056/NEJMoa2026920

95. Liu L, Wei Q, Lin Q, Fang J, Wang H, Kwok H, et al. Anti-spike IgG causes severe acute lung injury by skewing macrophage responses during acute SARS-CoV infection. JCI Insight (2019) 4(4):e123158. doi: 10.1172/ jci.insight. 123158

96. Shi J, Zhang J, Li S, Sun J, Teng Y, Wu M, et al. Epitope-Based Vaccine Target Screening against Highly Pathogenic MERS-CoV: An In Silico Approach Applied to Emerging Infectious Diseases. PloS One (2015) 10 (12):e0144475. doi: 10.1371/journal.pone.0144475

97. Song H, Wittman V, Byers A, Tapia T, Zhou B, Warren W, et al. In vitro stimulation of human influenza-specific CD8+ $\mathrm{T}$ cells by dendritic cells pulsed with an influenza virus-like particle (VLP) vaccine. Vaccine (2010) 28 (34):5524-32. doi: 10.1016/j.vaccine.2010.06.044

98. Liu YV, Massare MJ, Barnard DL, Kort T, Nathan M, Wang L, et al. Chimeric severe acute respiratory syndrome coronavirus (SARS-CoV) $\mathrm{S}$ glycoprotein and influenza matrix 1 efficiently form virus-like particles (VLPs) that protect mice against challenge with SARS-CoV. Vaccine (2011) 29(38):6606-13. doi: 10.1016/j.vaccine.2011.06.111

99. Sardesai NY, Weiner DB. Electroporation delivery of DNA vaccines: prospects for success. Curr Opin Immunol (2011) 23(3):421-9. doi: 10.1016/j.coi.2011.03.008

100. Nichols WW, Ledwith BJ, Manam SV, Troilo PJ. Potential DNA vaccine integration into host cell genome. Ann New Y Acad Sci (1995) 772:30-9. doi: 10.1111/j.1749-6632.1995.tb44729.x

101. Sheets RL, Stein J, Manetz TS, Duffy C, Nason M, Andrews C, et al. Biodistribution of DNA plasmid vaccines against HIV-1, Ebola, Severe Acute Respiratory Syndrome, or West Nile virus is similar, without integration, despite differing plasmid backbones or gene inserts. Toxicol Sci Off J Soc Toxicol (2006) 91(2):610-9. doi: 10.1093/toxsci/kfj169

102. Jaume M, Yip MS, Kam YW, Cheung CY, Kien F, Roberts A, et al. SARS CoV subunit vaccine: antibody-mediated neutralisation and enhancement. Hong Kong Med J Xianggang Yi Xue Za Zhi (2012) 18 Suppl 2:31-6.

103. Tseng C-T, Sbrana E, Iwata-Yoshikawa N, Newman PC, Garron T, Atmar $\mathrm{RL}$, et al. Immunization with SARS coronavirus vaccines leads to pulmonary immunopathology on challenge with the SARS virus. PloS One (2012) 7(4): e35421. doi: 10.1371/journal.pone.0035421 
104. Smith TRF, Patel A, Ramos S, Elwood D, Zhu X, Yan J, et al. Immunogenicity of a DNA vaccine candidate for COVID-19. Nat Commun (2020) 11(1):2601. doi: 10.1038/s41467-020-16505-0

105. Schlake T, Thess A, Fotin-Mleczek M, Kallen K-J. Developing mRNAvaccine technologies. RNA Biol (2012) 9(11):1319-30. doi: 10.4161/ rna.22269

106. Pardi N, Tuyishime S, Muramatsu H, Kariko K, Mui BL, Tam YK, et al. Expression kinetics of nucleoside-modified mRNA delivered in lipid nanoparticles to mice by various routes. $J$ Controlled Release Off $J$ Controlled Release Soc (2015) 217:345-51. doi: 10.1016/j.jconrel.2015.08.007

107. Bahl K, Senn JJ, Yuzhakov O, Bulychev A, Brito LA, Hassett KJ, et al. Preclinical and Clinical Demonstration of Immunogenicity by mRNA Vaccines against H10N8 and H7N9 Influenza Viruses. Mol Ther J Am Soc Gene Ther (2017) 25(6):1316-27. doi: 10.1016/j.ymthe.2017.03.035

108. Selmi A, Vascotto F, Kautz-Neu K, Türeci Ö, Sahin U, von Stebut E, et al. Uptake of synthetic naked RNA by skin-resident dendritic cells via macropinocytosis allows antigen expression and induction of T-cell responses in mice. Cancer Immunol Immunother CII (2016) 65(9):107583. doi: 10.1007/s00262-016-1869-7

109. Granstein RD, Ding W, Ozawa H. Induction of anti-tumor immunity with epidermal cells pulsed with tumor-derived RNA or intradermal administration of RNA. J Invest Dermatol (2000) 114(4):632-6. doi: 10.1046/j.1523-1747.2000.00929.x

110. Kreiter S, Selmi A, Diken M, Koslowski M, Britten CM, Huber C, et al. Intranodal vaccination with naked antigen-encoding RNA elicits potent prophylactic and therapeutic antitumoral immunity. Cancer Res (2010) 70 (22):9031-40. doi: 10.1158/0008-5472.CAN-10-0699

111. Bialkowski L, van Weijnen A, Van der Jeught K, Renmans D, Daszkiewicz L, Heirman $\mathrm{C}$, et al. Intralymphatic mRNA vaccine induces CD8 T-cell responses that inhibit the growth of mucosally located tumours. Sci Rep (2016) 6:22509. doi: 10.1038/srep22509

112. Theofilopoulos AN, Baccala R, Beutler B, Kono DH. Type I interferons (alpha/beta) in immunity and autoimmunity. Annu Rev Immunol (2005) 23:307-36. doi: 10.1146/annurev.immunol.23.021704.115843

113. Nestle FO, Conrad C, Tun-Kyi A, Homey B, Gombert M, Boyman O, et al. Plasmacytoid predendritic cells initiate psoriasis through interferon-alpha production. J Exp Med (2005) 202(1):135-43. doi: 10.1084/jem.20050500

114. Fischer S, Gerriets T, Wessels C, Walberer M, Kostin S, Stolz E, et al. Extracellular RNA mediates endothelial-cell permeability via vascular endothelial growth factor. Blood (2007) 110(7):2457-65. doi: 10.1182/ blood-2006-08-040691

115. Kannemeier C, Shibamiya A, Nakazawa F, Trusheim H, Ruppert C, Markart P, et al. Extracellular RNA constitutes a natural procoagulant cofactor in blood coagulation. Proc Natl Acad Sci U States America (2007) 104(15):6388-93. doi: 10.1073/pnas.0608647104

116. Alberer M, Gnad-Vogt U, Hong HS, Mehr KT, Backert L, Finak G, et al. Safety and immunogenicity of a mRNA rabies vaccine in healthy adults: an open-label, non-randomised, prospective, first-in-human phase 1 clinical trial. Lancet (London England) (2017) 390(10101):1511-20. doi: 10.1016/ S0140-6736(17)31665-3

117. Corbett KS, Flynn B, Foulds KE, Francica JR, Boyoglu-Barnum S, Werner AP, et al. Evaluation of the mRNA-1273 Vaccine against SARS-CoV-2 in Nonhuman Primates. N Engl J Med (2020) 383(16):1544-55. doi: 10.1056/ NEJMoa2024671

118. Jackson LA, Anderson EJ, Rouphael NG, Roberts PC, Makhene M, Coler RN, et al. An mRNA Vaccine against SARS-CoV-2 - Preliminary Report. New Engl J Med (2020) 383(20):1920-31. doi: 10.1056/NEJMoa2022483

119. Walsh EE, Frenck RW, Falsey AR, Kitchin N, Absalon J, Gurtman A, et al. Safety and Immunogenicity of Two RNA-Based Covid-19 Vaccine Candidates. N Engl J Med (2020). doi: 10.1056/NEJMoa2027906

120. Zhang NN, Li XF, Deng YQ, Zhao H, Huang YJ, Yang G, et al. A Thermostable mRNA Vaccine against COVID-19. Cell (2020) 182 (5):1271-83.e16. doi: 10.1016/j.cell.2020.07.024

121. Kalnin KV, Plitnik T, Kishko M, Zhang J, Zhang D, Beauvais A, et al. Immunogenicity of novel mRNA COVID-19 vaccine MRT5500 in mice and non-human primates. bioRxiv [Preprint] (2020) 2020.10.14.337535. doi: $10.1101 / 2020.10 .14 .337535$
122. Tai W, Zhang X, Drelich A, Shi J, Hsu JC, Luchsinger L, et al. A novel receptor-binding domain (RBD)-based mRNA vaccine against SARS-CoV-2. Cell Res (2020) 30(10):932-5. doi: 10.1038/s41422-020-0387-5

123. Fuller DH, Berglund P. Amplifying RNA Vaccine Development. N Engl J Med (2020) 382(25):2469-71. doi: 10.1056/NEJMcibr2009737

124. de Alwis R, Gan ES, Chen S, Leong YS, Tan HC, Zhang SL, et al. A Single Dose of Self-Transcribing and Replicating RNA Based SARS-CoV-2 Vaccine Produces Protective Adaptive Immunity In Mice. bioRxiv [Preprint] (2020) 2020.09.03.280446. doi: 10.1101/2020.09.03.280446

125. Tang J, Zhang N, Tao X, Zhao G, Guo Y, Tseng C-TK, et al. Optimization of antigen dose for a receptor-binding domain-based subunit vaccine against MERS coronavirus. Hum Vaccines Immunotherapeut (2015) 11(5):1244-50. doi: 10.1080/21645515.2015.1021527

126. Schindewolf C, Menachery VD. Middle East Respiratory Syndrome Vaccine Candidates: Cautious Optimism. Viruses (2019) 11(1):74. doi: 10.3390/ v11010074

127. Chirmule N, Propert K, Magosin S, Qian Y, Qian R, Wilson J. Immune responses to adenovirus and adeno-associated virus in humans. Gene Ther (1999) 6(9):1574-83. doi: 10.1038/sj.gt.3300994

128. Mast TC, Kierstead L, Gupta SB, Nikas AA, Kallas EG, Novitsky V, et al. International epidemiology of human pre-existing adenovirus (Ad) type-5, type-6, type- 26 and type- 36 neutralizing antibodies: correlates of high Ad5 titers and implications for potential HIV vaccine trials. Vaccine (2010) 28 (4):950-7. doi: 10.1016/j.vaccine.2009.10.145

129. Zhang Q, Seto D. Chimpanzee Adenovirus Vector Ebola VaccinePreliminary Report. N Engl J Med (2015) 373(8):775-6. doi: 10.1056/ NEJMc1505499

130. Farina SF, Gao GP, Xiang ZQ, Rux JJ, Burnett RM, Alvira MR, et al. Replication-defective vector based on a chimpanzee adenovirus. $J$ Virol (2001) 75(23):11603-13. doi: 10.1128/JVI.75.23.11603-11613.2001

131. Folegatti PM, Ewer KJ, Aley PK, Angus B, Becker S, Belij-Rammerstorfer S, et al. Safety and immunogenicity of the ChAdOx $1 \mathrm{nCoV}-19$ vaccine against SARS-CoV-2: a preliminary report of a phase $1 / 2$, single-blind, randomised controlled trial. Lancet (2020) 396(10249):467-78. doi: 10.1016/S0140-6736 (20)31604-4

132. Zhu F-C, Li Y-H, Guan X-H, Hou L-H, Wang W-J, Li J-X, et al. Safety, tolerability, and immunogenicity of a recombinant adenovirus type- 5 vectored COVID-19 vaccine: a dose-escalation, open-label, nonrandomised, first-in-human trial. Lancet (2020) 395(10240):1845-54. doi: 10.1016/S0140-6736(20)31208-3

133. Zhu F-C, Guan X-H, Li Y-H, Huang J-Y, Jiang T, Hou L-H, et al. Immunogenicity and safety of a recombinant adenovirus type-5-vectored COVID-19 vaccine in healthy adults aged 18 years or older: a randomised, double-blind, placebo-controlled, phase 2 trial. Lancet (2020) 396 (10249):479-88. doi: 10.1016/S0140-6736(20)31605-6

134. Feng L, Wang Q, Shan C, Yang C, Feng Y, Wu J, et al. An adenovirusvectored COVID-19 vaccine confers protection from SARS-COV-2 challenge in rhesus macaques. Nat Commun (2020) 11(1):4207. doi: 10.1038/s41467-020-18077-5

135. Logunov DY, Dolzhikova IV, Zubkova OV, Tukhvatullin AI, Shcheblyakov DV, Dzharullaeva AS, et al. Safety and immunogenicity of an rAd26 and rAd5 vector-based heterologous prime-boost COVID-19 vaccine in two formulations: two open, non-randomised phase 1/2 studies from Russia. Lancet (2020) 396(10255):887-97. doi: 10.1016/S0140-6736(20)31866-3

136. Sadoff J, Le Gars M, Shukarev G, Heerwegh D, Truyers C, de Groot AM, et al. Safety and immunogenicity of the Ad26.COV2.S COVID-19 vaccine candidate: interim results of a phase $1 / 2 \mathrm{a}$, double-blind, randomized, placebo-controlled trial. medRxiv [Preprint] (2020) 2020.09.23.20199604. doi: $10.1101 / 2020.09 .23 .20199604$

137. Agnihothram S, Gopal R, Yount BL, Donaldson EF, Menachery VD, Graham $\mathrm{RL}$, et al. Evaluation of serologic and antigenic relationships between middle eastern respiratory syndrome coronavirus and other coronaviruses to develop vaccine platforms for the rapid response to emerging coronaviruses. J Infect Dis (2014) 209(7):995-1006. doi: 10.1093/infdis/jit609

138. Zhou P, Yang X-L, Wang X-G, Hu B, Zhang L, Zhang W, et al. A pneumonia outbreak associated with a new coronavirus of probable bat origin. Nature (2020) 579(7798):270-3. doi: 10.1038/s41586-020-2012-7 
139. Yong CY, Ong HK, Yeap SK, Ho KL, Tan WS. Recent Advances in the Vaccine Development Against Middle East Respiratory SyndromeCoronavirus. Front Microbiol (2019) 10:1781. doi: 10.3389/fmicb.2019.01781

140. Wang S-F, Tseng S-P, Yen C-H, Yang J-Y, Tsao C-H, Shen C-W, et al. Antibody-dependent SARS coronavirus infection is mediated by antibodies against spike proteins. Biochem Biophys Res Commun (2014) 451(2):208-14. doi: 10.1016/j.bbrc.2014.07.090

141. Du L, Tai W, Zhou Y, Jiang S. Vaccines for the prevention against the threat of MERS-CoV. Expert Rev Vaccines (2016) 15(9):1123-34. doi: 10.1586/ 14760584.2016.1167603

142. Liu C, Mendonca L, Yang Y, Gao Y, Shen C, Liu J, et al. The Architecture of Inactivated SARS-CoV-2 with Postfusion Spikes Revealed by Cryo-EM and Cryo-ET. Structure (2020) 28(11):1218-24.e4. doi: 10.1016/j.str.2020.10.001

143. McLellan JS, Chen M, Leung S, Graepel KW, Du X, Yang Y, et al. Structure of RSV fusion glycoprotein trimer bound to a prefusion-specific neutralizing antibody. Sci (N Y NY) (6136) 2013) 340:1113-7. doi: 10.1126/science.1234914

144. Killikelly AM, Kanekiyo M, Graham BSJSR. Pre-fusion F is absent on the surface of formalin-inactivated respiratory syncytial virus. Sci Rep (2016) 6:34108. doi: 10.1038/srep34108

145. Ou J, Zhou Z, Dai R, Zhao S, Wu X, Zhang J, et al. Emergence of SARS-CoV2 spike RBD mutants that enhance viral infectivity through increased human
ACE2 receptor binding affinity. BioRxiv [Preprint] (2020) 2020.03.15.991844. doi: 10.1101/2020.03.15.991844\%JbioRxiv

146. Li Q, Wu J, Nie J, Zhang L, Hao H, Liu S, et al. The Impact of Mutations in SARS-CoV-2 Spike on Viral Infectivity and Antigenicity. Cell (2020) 182 (5):1284-94.e9. doi: 10.1016/j.cell.2020.07.012

147. Korber B, Fischer WM, Gnanakaran S, Yoon H, Theiler J, Abfalterer W, et al. Tracking Changes in SARS-CoV-2 Spike: Evidence that D614G Increases Infectivity of the COVID-19 Virus. Cell (2020) 182(4):812-27.e19. doi: 10.1016/j.cell.2020.06.043

Conflict of Interest: The authors declare that the research was conducted in the absence of any commercial or financial relationships that could be construed as a potential conflict of interest.

Copyright (c) 2020 Zhao, Zhao, Ou, Zhang, Lan, Guan, Wu, Yan, Zhao, Wu, Chodosh and Zhang. This is an open-access article distributed under the terms of the Creative Commons Attribution License (CC BY). The use, distribution or reproduction in other forums is permitted, provided the original author(s) and the copyright owner(s) are credited and that the original publication in this journal is cited, in accordance with accepted academic practice. No use, distribution or reproduction is permitted which does not comply with these terms. 